Review

Subscriber access provided by King Abdullah University of Science and Technology Library

\title{
Proteomics of Important Food Crops in the Asia Oceania Region: Current Status and Future Perspectives
}

Subhra Chakraborty, Ghasem Hosseini Salekdeh, Pingfang Yang, Sun-Hee Woo, Chiew Foan Chin, Chris Gehring, Paul A. Haynes, Mehdi Mirzaei, and Setsuko Komatsu

J. Proteome Res., Just Accepted Manuscript • DOI: 10.1021/acs.jproteome.5b00211 • Publication Date (Web): 02 Jun 2015

Downloaded from http://pubs.acs.org on June 8, 2015

\section{Just Accepted}

"Just Accepted" manuscripts have been peer-reviewed and accepted for publication. They are posted online prior to technical editing, formatting for publication and author proofing. The American Chemical Society provides "Just Accepted" as a free service to the research community to expedite the dissemination of scientific material as soon as possible after acceptance. "Just Accepted" manuscripts appear in full in PDF format accompanied by an HTML abstract. "Just Accepted" manuscripts have been fully peer reviewed, but should not be considered the official version of record. They are accessible to all readers and citable by the Digital Object Identifier (DOI®). "Just Accepted" is an optional service offered to authors. Therefore, the "Just Accepted" Web site may not include all articles that will be published in the journal. After a manuscript is technically edited and formatted, it will be removed from the "Just Accepted" Web site and published as an ASAP article. Note that technical editing may introduce minor changes to the manuscript text and/or graphics which could affect content, and all legal disclaimers and ethical guidelines that apply to the journal pertain. ACS cannot be held responsible for errors or consequences arising from the use of information contained in these "Just Accepted" manuscripts. 


\section{Proteomics of Important Food Crops in the Asia Oceania Region: Current Status and Future Perspectives}

Subhra Chakraborty ${ }^{1)}$, Ghasem Hosseini Salekdeh ${ }^{2)}$, Pingfang Yang ${ }^{3)}$, Sun Hee Woo ${ }^{4)}$, Chiew Foan Chin $^{5)}$, Chris Gehring ${ }^{6)}$, Paul A. Haynes ${ }^{7, *}$, Mehdi Mirzaei ${ }^{7)}$ and Setsuko $\mathrm{Komatsu}^{8, *)}$

1) National Institute of Plant Genome Research, New Delhi, India

2) Agricultural Biotechnology Research Institute of Iran, Karaj, Iran

3) Wuhan Botanical Garden, Chinese Academy of Sciences, Wuhan, China

4) Chungbuk National University, Cheongju, Korea

5) University of Nottingham Malaysia Campus, Malaysia

6) King Abdullah University of Science and Technology, Thuwal, Kingdom of Saudi Arabia

7) Macquarie University, Sydney, Australia

8) National Institute of Crop Science, Tsukuba, Japan

*Corresponding Authors:

Setsuko Komatsu, National Institute of Crop Science, Tsukuba, Japan, E-mail: skomatsu@affrc.go.jp

Paul A. Haynes, Macquarie University, Sydney, Australia, E-mail:

paul.haynes@mq.edu.au

ABBREVIATIONS: MS, mass spectrometry; 2-DE, two-dimensional electrophoresis;

LC, liquid chromatography; ROS, reactive oxygen species 


\begin{abstract}
In the rapidly growing economies of Asia and Oceania, food security has become a primary concern. With the rising population, growing more food at affordable prices is becoming even more important. In addition, the predicted climate change will lead to drastic changes in global surface temperature and changes in rainfall patterns that in turn would pose a serious threat to plant vegetation worldwide. As a result, understanding how plants will survive in a changing climate will be increasingly important. Such challenges require integrated approaches to increase agricultural production and cope with environmental threats. Proteomics can play a role in unravel the underlying mechanisms for food production to address the growing demand for food. In this review, the current status of food crop proteomics is discussed, especially in regards to the Asia and Oceania regions. Furthermore, the future perspective in relation to proteomic techniques for the important food crops is highlighted.
\end{abstract}

KEYWORDS: food crop, proteomics, review 


\section{INTRODUCTION}

The impact of human civilization on our planet is one of the greatest challenges facing the world today, as it is clear that our activities are causing significant changes to the environment. Among these changes, climate change, whether naturally occurring or due to anthropogenic causes, has received considerable attention ${ }^{1}$. In the rapidly growing economies of Asia and Oceania ${ }^{2}$, food security has become a priority concern

${ }^{3}$. With a rising population, growing more food at affordable prices is becoming even more important. Models from climate forecasts have predicted drastic changes in global surface temperature that could lead to changes in rainfall patterns. This in turn would pose a serious threat to vegetation worldwide. Facing such are challenge requires the development of integrated approaches to increase agricultural production and cope with environmental threats ${ }^{2}$. An important challenge for plant breeding is to identify the genes responsible for important crop traits, especially in food crops. These complex traits are normally governed by polygenes which are not easy to analyze. To overcome this hurdle, an alternative approach through application of high throughput technologies is essential.

Proteomics can play a role in addressing the growing demand for food, by providing fundamental molecular level knowledge that can be used in characterizing the properties of different plant varieties, and also by identifying molecular markers for use in selective breeding programs ${ }^{4}$. The advent of proteomics has allowed researchers to identify a broad spectrum of proteins in living systems. This information is especially useful for agriculture because it may provide clues to the nutritional value, yield potential, and inherent adaptability of the crops under stress conditions. To promote agricultural proteomic activities in the Asia and Oceania regions, the Asia Oceania 
Agricultural Proteome Organization (AOAPO) was established in $2010^{2}$. This organization aims to foster collaborations among researchers working on agricultural proteomics in the regions.

In the last two decades, plant proteomic studies have largely been confined to using model plant species such as Arabidopsis for dicots and rice for monocots, due to the availability of a complete genome sequence, and large volumes of scientific information ${ }^{5-11}$. However, it is imperative that the knowledge acquired in the proteomic studies of these model species be extended to other food crops species in order to provide more impactful benefits to society. Today, translational plant proteomic studies have become increasingly important and prominent in the proteomics field ${ }^{12-14}$.

Plant proteomics has traditionally lagged behind proteomics in other fields, partly due to the difficulties involved in sample preparation from green tissues containing high levels of metabolites, oils, antioxidants and other non-proteinaceous molecular species. That gap is gradually closing as improvements in sample preparation procedures mean that plant tissues can now be analysed using state-of-the-art chemical isotopic labelling approaches ${ }^{15,16}$. One other traditional limitation was the dearth of genome sequence information available for plant species, especially crop plants, but that has been alleviated by the publication of numerous complete plant genome sequences in recent years, such as the chromosome-based draft sequence of the hexaploid bread wheat genome ${ }^{17}$. Salekdeh and Komatsu ${ }^{12}$ have published a previous review article on crop proteomics. In the current review, proteomics data of food crops since 2008 is presented (Table 1) and the future perspective for important crops is discussed in relation to the current proteomic techniques. The aim of this review is to provide an introduction to the recent relevant literature in the application of proteomics to a specific set of crop plants, as detailed in the following sections. 
AGRICULTURAL PROBLEMS AND THE CURRENT STATUS OF CROP PROTEOMICS

\section{The Current Status of Proteomics in Rice}

Rice is the staple food for the world population, especially in Southeast Asia ${ }^{18}$, and it is also a model monocot in plant biology. Because of its compact genome among the cereals, its genome has been fully sequenced and annotated ${ }^{19,20}$, which provides a fundamental database resource for use in proteomic studies. Except for Arabidopsis, rice may be the most extensively studied plant species, including proteomics.

Compared with Arabidopsis, rice seems to have a longer history of proteomic studies ${ }^{21}$, and it could be argued that rice proteomics has been a major topic of interest in rice biology. A large number of extensive reviews have comprehensively summarized the progress in rice proteomics ${ }^{22}$. In this review, we will focus on the application of proteomics in solving the problems related to rice agricultural practices. Essentially, the studies could be sorted into two major aspects: growth and development, and stress responses (Table 1).

\section{Growth and development}

The main purpose of rice production is to obtain high yield of good quality seeds, which provides the main food resource. To achieve this, rice plants should be healthy throughout their life cycle. Seed viability, and vigor of seed and seedling, determine the health of seedling and the first committed step is the seed germination. Extensive proteomic studies have been conducted in recent years ${ }^{23}$. Profiling and dynamic analysis of germinating rice seed proteome have shown the mechanistic behavior of 
carbon flux from endosperm to embryo ${ }^{24,25}$. These studies also indicated that embryo play the major role during rice seed germination ${ }^{26}$, and phytohormones including ABA, GA and BR are involved in the regulation of this process ${ }^{27,28}$.

During vegetative growth, seedling establishment and plant architecture are the two major agronomic traits for rice. Studies have shown that proteins involved in light induction of chlorophyll biosynthesis and recovery of chloroplast structure are very important for the seedling photo-morphogenesis ${ }^{29}$. Furthermore, many of these proteins were proved to be rhythmic in nature, with their expression controlled by either endogenous circadian clocks or exogenous signals in the form of diurnal changes in light and temperature ${ }^{30,31}$. Studies on leaf, stem and root showed that photosynthesis and energy production related proteins are more abundant in leaf and stem, while defense and ion absorption related proteins are more abundant in $\operatorname{root}^{32}$. Specifically, very abundant cell structure and cell wall related proteins are accumulated in stems at the late stage of growth, which is consistent with their physiological functions ${ }^{33}$.

In rice, pollen has also been extensively studied ${ }^{34}$. A number of proteomic studies have also been conducted on anthers ${ }^{35,36}$. Very recently, proteomic analyses were conducted on the cytoplasmic male sterile rice lines because of its importance in hybrid rice breeding ${ }^{37,38}$. Compared with male gametophytes, the proteomic study on female gametophytes is just at the beginning stage. However, with the advancement in technology, some new techniques were applied along with the proteomic studies in pistil or ovules ${ }^{34,39}$. Since seeds are the major product in rice production, study on seed development is also a key aspect in rice proteomics, which mainly focusses on embryogenesis and grain filling ${ }^{15,40-43}$. 
Stress responses

With the industrialization and changes in world climate, crops are facing more and more abiotic stresses. Meanwhile, numerous diseases and pests have posed serious threats to rice production. Proteomics studies on abiotic or biotic stress responses in rice therefore may help to identify the key regulators and contribute to the development of new cultivars with enhanced stress resistance.

To date, studies on abiotic stress-responsive proteomes account for more than $60 \%$ of the rice proteomics studies. Among the abiotic stresses, drought and salinity are the two most serious threats. Proteomics have been conducted on different genotypes and different tissues such as leaf, root, shoot, anther, and peduncles; these have been extensively discussed in two recent reviews ${ }^{22,44}$. Due to the ease of handling, seedlings are the most popular materials that have been used for the studies. In many rice cultivation areas located near mining industry, heavy metal pollution has been a serious problem. As a result, the yields of rice were affected. In addition, the heavy metals can accumulate in the rice grain and cause harm to human health. Therefore, proteomics studies were also conducted on rice in response to the heavy metals in the last few years ${ }^{45,46}$. Extreme temperature is harmful to rice growth, especially during the reproductive phase. Although proteomic analyses on vegetative tissues have identified a series of cold or high temperature specific proteins in rice ${ }^{47,48}$, studies on reproductive tissue such as anther ${ }^{49}$ have been found to be more informative in rice production. Overall, the studies showed that different abiotic stresses could negatively affect photosynthesis and energy machinery in rice and hence reduce its growth and yield. Meanwhile, enhancement of reactive oxygen species (ROS) scavenging systems might help rice to survive from the stresses.

During rice cultivation, different biotic stresses from pathogen and pests could 
lead to serious yield losses. In plants, pattern recognition receptors (PRRs), belonging to receptor-like kinases (RLKs) or receptor like proteins (RLPs) at the cell surface, can recognize pathogen derives molecules and activate a series of immune responses ${ }^{50}$. In the rice genome, there are more than $1100 \mathrm{RLK} / \mathrm{P}$ genes, among which OsRacGEF1 and OsRLCK185 have been shown to be involved in pathogen signaling pathways ${ }^{50}$. However, most of the components in the pathway are still unknown. Identification of signaling components in rice and virus proteins in pathogens are of equal importance. A large number of proteomics studies have been conducted on rice blast ${ }^{51-53}$ and blight diseases ${ }^{54,55}$, which are caused by Magnaporthe oryzae and Xanthomonas oryzae, respectively. These studies show that the level of OsPR10 was increased by different biotic stresses ${ }^{22}$, indicating that it might play an important role in rice disease resistance. Proteomic analyses were also conducted on a serious rice pest, the brown planthopper ${ }^{56,57}$, which showed that jasmonic acid and ROS signaling pathways might contribute to rice resistance to this pest.

\section{The Current Status of Proteomics in Maize}

Maize, together with wheat and rice, provides at least $30 \%$ of the food calories to more than 4.5 billion people across 94 developing countries including 900 million poor consumers for whom it is the preferred staple ${ }^{58}$. Maize is grown under temperatures ranging from cool to very hot, on wet to semi-arid lands, and in many different types of soils and over a wider range of altitudes and latitudes than any other food crop. The global area of maize plantings is about 150 million hectares ${ }^{59}$. Maize demand is significantly diversified as it includes human consumption, livestock feed, industrial processing, seed and other alternative uses. At the global level, $63 \%$ of the maize demand is for livestock feed and in the developing countries this currently stands at 
around $56 \%$. While $70 \%$ of maize is used as animal feed and only $3 \%$ for food in the high income countries, in sub-Saharan Africa outside of South Africa more than two-thirds of maize is used for direct human consumption and only about $18-20 \%$ as animal feed ${ }^{59}$.

Maize has also served as a model plant for studying the biology and genetics of monocots since the beginning of the 20th century. Currently, one of the most systematically studied genetic systems is found in maize ${ }^{60}$. The availability of the maize genomic sequence, and the wealth of genomic and genetic information accessible in public repositories, have accelerated the advances in maize research including the analysis of the maize proteome.

Many research groups have utilized various proteomics tools in maize studies including proteome profiling, subcellular proteomics, developmental proteomics, as well as abiotic and biotic stress proteomics (reviewed by ${ }^{61}$ ) (Table 1). Proteomics approaches have been employed for profiling of root hair proteins ${ }^{62}$, profiling of pollen and pistil proteins ${ }^{63}$, identification of pollen coat proteins ${ }^{64}$, establishment of a reference map of nuclear proteins in basal region of seedling leaf ${ }^{65}$, identification of proteins involved in grain filling rate ${ }^{66}$, discrimination of two traditional maize inbred lines of contrasting technological abilities by the seed flour proteome ${ }^{67}$, analysis of the mechanism of heterosis in radicle emergence ${ }^{68}$, changes in the abundance of proteins during cold pretreatment and subsequent cultivation of maize anthers on induction media ${ }^{69}$, short-term effects of salt exposures on chloroplasts ${ }^{70}$, the effect of moderate short-term salt stress on phosphorylation of proteins in a salt tolerant genotype ${ }^{71}$, deciphering the role of nitrogen oxide in enhancing maize tolerance to salt stress ${ }^{72}$, germinating seeds response to salt stress ${ }^{73}$, changes in the xylem sap proteome in response to drought stress ${ }^{74}$, desiccation tolerance of embryos during their 
development and germination ${ }^{75}$, cell wall protein response to water deficit ${ }^{76}$, changes in root proteins under phosphorus deficit ${ }^{77}$, identification of proteins responsive to sugarcane mosaic virus in maize seedling ${ }^{78}$, identification of flooding stress related programmed cell death proteins ${ }^{79}$, and the effects of salicylic acid and abscisic acid on leaf proteome ${ }^{80}$. In the last decade, high-throughput quantitative proteomics studies on the chloroplasts of $\mathrm{C}_{4}$ plant maize have been carried out by several groups ${ }^{81-83}$.

All of the above proteomic studies contributed to the identification of new developmentally or stress regulated proteins. In addition, the studies enable better understanding of maize development at the cellular, tissue, and organ levels and its response to abiotic and biotic stresses. The major advantage of these proteomic studies is that information on multiple biochemical and physiological processes and growth conditions in revealing several novel developmental or stress response pathways.

Walley et al. ${ }^{84}$ generated an atlas of maize seed proteotypes by using MS that quantifies protein abundance and phosphorylation levels across developmental time. The atlas is the most complete, quantitative proteome to date and includes 14,165 proteins and 18,405 phosphopeptides. The relationship between mRNA and protein levels in the endosperm and in the embryo was also compared using proteome data with publically available transcript profiling data. The results showed the lack of concordance between mRNA and protein levels. It was also observed that phosphorylation level and protein abundance were largely independent. Furthermore, individual sites of phosphorylation showed tissue-specific levels that were not dictated by protein abundance. The atlas was used to reconstruct protein networks for key biochemical processes and for developmental pathways, which add significantly to our understanding of seed development, and should facilitate knowledge-based crop improvement. 
Facette et al. ${ }^{85}$ also performed parallel proteomic and phosphoproteomic analyses of developing maize leaves using a label-free proteomics method. They quantified peptides and phosphopeptides from four developmental zones of the leaf and identified more than 81,000 peptides from over 12,000 proteins and over 11,000 phosphorylated peptides from more than 3,500 proteins. They provided both quantitative and qualitative information about the distribution of maize proteins and their phosphorylation status through successive stages of maize leaf development.

Rapidly improving MS instrumentation and recent advances in bioinformatics have enabled the field of proteogenomics, using proteomic information to annotate the genome ${ }^{86}$. Proteogenomics complements DNA-based annotation and unambiguously determines reading frame, translation start and stop sites, splice boundaries, and the validity of short ORFs. A more accurate and complete protein-coding catalog can be obtained by combining nucleotide-based annotation with proteogenomics.

Castellana et al. ${ }^{87}$ employed a semi-automated proteogenomic approach to annotate the maize genome. This study presented one of the largest proteogenomic efforts undertaken on a single organism. The maize genome is particularly challenging due to its large size ( 2 billion nucleotides) and many repetitive regions ${ }^{60}$. To control the false discovery rate, a framework for evaluating the quality of MS-based discovery of gene refinement 'events' was developed. In this framework, peptides that appear in multiple locations in addition to uniquely mapping peptides were utilized for scoring novel discoveries. More than 109 million tandem mass spectra created from maize seeds at multiple stages of development were analyzed. A revised genome annotation was presented with updated gene models for 741 genes and the addition of 165 novel protein coding genes. 


\section{The Current Status of Proteomics in Wheat}

Next to rice, wheat is regarded as one of the major cereal crops in the world and is a widely utilized crop for intensive breeding and selection for about a century ${ }^{88}$. From the perspectives of global food security, wheat plays a major role as staple food ${ }^{89}$ and it is considered to be one of the three most important crops in the world for its food value and unique potential for bread production ${ }^{90}$. However, research studies at the molecular level on wheat have been significantly less than in other plant species, especially the model plants, rice and Arabidopsis, due to the size and complexity of the wheat genome ${ }^{91}$.

The major focus of agricultural research is on the vast economic losses caused by the various environmental conditions, especially abiotic stresses such as drought, salinity, submergence and anoxia, extreme temperatures, chemical (mineral) toxicities and deficiencies, and oxidative and low nutrient stress. The abiotic stresses undoubtedly are perceived as serious threats to agriculture because they affect the quality, yield and characteristics of the final product ${ }^{92}$. Eventually, they will have significant impact on the food production capacity to meet the demands of an increasing global population ${ }^{93}$. Among the abiotic stresses, drought, high temperature and salinity are identified as the major causes of grain yield loss, with more than $50 \%$ losses reported ${ }^{94}$. Drought stress is considered as the most serious environmental factor that impairs plant growth, productivity and distribution ${ }^{95}$. Water deficiency alters plant morphology, growth, and metabolism, and will ultimately reduce grain yield in most regions of the world ${ }^{96}$. Temperature stress, another important environmental factor, has a direct effect on wheat quality. During grain filling, high temperature severely affects the drought tolerance properties and quality of different wheat varieties grown as crops in different parts of the world ${ }^{97}$. In addition, extreme 
high temperature shortens the grain filling period after anthesis, which leads to reduced kernel weight as well as changes in grain quality parameters such as starch and protein content ${ }^{98}$. Low temperature is also another major concern in the wheat industry. Wheat is considered as a comparatively cold-tolerant crop. However, low temperature during winter and spring limits wheat productivity and yield ${ }^{99}$. Salinization of soils is a severe impediment to cereal productivity mainly in the arid and semi- arid regions ${ }^{100}$. It has been reported that salinity stress has impacts on crop production in at least $20 \%$ of irrigated land worldwide ${ }^{101}$. Wheat is a salt-sensitive glycophyte that is severely affected by salinity, which results in considerable reduction in grain yield ${ }^{102}$. Besides abiotic stresses, there are other factors that may contribute to a reduction in wheat production. Pre-harvest sprouting is considered as a major limitation for wheat when long range rainfall or damp conditions prevail prior to harvest ${ }^{103}$. On the economic and nutritional aspects, studies have suggested that high temperature may affect dough making and grain quality ${ }^{97,98,104}$ as well as kernel characteristics ${ }^{92}$.

Recently, considerable progress has been made in proteome research on wheat. Diverse abiotic stress factors considerably limit crop yield in wheat (Table 1). Drought stress has serious consequences on wheat growth and yield and has a huge economic impact, especially in agricultural production. Several proteomics studies have been carried out using 2-DE based proteomics in wheat during drought stress on seed ${ }^{105}$, peduncle ${ }^{95}$, leaf ${ }^{88,106,107}$, leaf pigment ${ }^{89,95,108}$, and grain ${ }^{109,110}$. More recently, large numbers of proteins were identified using nanoflow liquid chromatography (LC)-ESI/MS-MS ${ }^{111}$. Salt stress is regarded as another major abiotic stress that severely affects the wheat production, especially seed. To date, most of the protein studies on wheat have focused on tissues and organs such as leaf ${ }^{100,102}$, seed ${ }^{112,113}$, $\operatorname{root}^{101}$, mitochondria ${ }^{91}$ and seed priming ${ }^{114}$. Low temperature has turned out to be 
severe environmental stress which impairs wheat yield and productivity worldwide. Recent proteomic investigations into cold stress show that this is an area of great concern in wheat research. Recent studies involving wheat under cold stress have included analysis of seed ${ }^{115}$, leaf ${ }^{116,117}$, crown ${ }^{102,118}$ and spike development ${ }^{119}$.

Improvement of grain quality has become a promising area of research interest in wheat breeding. The recent advances in wheat grain proteomics have been carried out in various wheat cultivars ${ }^{120}$, endosperm ${ }^{121,122}$, grain storage proteins ${ }^{90,103,123-128}$, mature embryo ${ }^{129}$ and flour quality ${ }^{130}$. Wheat proteomics have also provided knowledge on the effect of radiation ${ }^{131}$ and various metal toxicities such as cadmium ${ }^{132}$, aluminum ${ }^{133}$, and copper ${ }^{134}$. Recently, researchers have conducted proteomics studies on roots under abscisic acid stress ${ }^{135}$, root under flooding stress ${ }^{136}$ and leaf ${ }^{16,137}$, all of which would help the wheat research community in the future.

\section{The Current Status of Proteomics in Barley}

Barley is among the earliest of the domesticated crop species and is now among the most widely cultivated crops in the world. It is often grown in marginal areas and environments because it is relatively tolerant of many abiotic stresses, and is known to be more stress-tolerant than wheat which is a close relative. Barley has been shown to rapidly adapt to changing environmental conditions. In a groundbreaking study of wild barley sampled in Israel across a 28 year timespan, the authors observed profound adaptive changes in flowering time and sequence repeat allelic turnover ${ }^{138}$. Since barley has been cultivated for a historically long time by mankind, there are an enormous number of different varieties available which have been selectively bred over long time periods for specific purposes. Many of these can be traced back to adaptation to climate conditions prevalent in a particular geographic location; for 
example, barley which has been bred for many generations in the Middle East and North Africa is highly tolerant of the hot and dry conditions typical of those areas. Approximately $75 \%$ of global barley production is used in animal feed stocks, $20 \%$ is used in preparation of both non-alcoholic and alcoholic beverages, and the remaining 5\% is used as an ingredient in a wide range of food products. In developing countries, however, the usage profile is dramatically different; barley remains a major food source, and demand continues to outstrip supply ${ }^{139}$. In first world countries, barley is becoming increasingly popular as a functional foodstuff, due to its high levels of soluble dietary fibre. This is known to significantly reduce risk from several widespread and serious human diseases, including cardiovascular disease, colorectal cancer, and even some forms of type II diabetes. Barley has a long and proud history of human cultivation ${ }^{140}$, and it is reasonable to expect that this will continue due to the sustained level of demand. There is considerable research in progress focusing on analysis of wild varieties of barley, as these are anticipated to contain genetic information that could allow development of barley varieties with, for example, even greater levels of dietary fibre present in the grain (with increased levels of associated health benefits), or enhanced ability to grow productively in ever more marginal areas, and withstand ever more harsh climates ${ }^{141}$.

Previous studies in barley proteomics have included (Table 1), for example, 2-DE gel based studies examining changes in protein abundance in grains of different barley varieties during development ${ }^{142}$, changes in leaf and shoot proteins in response to heat stress ${ }^{143}$, identification of protein signatures associated with malting quality ${ }^{144}$, identification of changes in the root and shoot proteomes caused by both long and short term nitrogen deficiency ${ }^{145}$, characterisation of the spatiotemporal changes in radicle elongation in barley seeds ${ }^{146}$, identification of proteins associated with cadmium 
accumulation in genotypes with differing levels of cadmium tolerance ${ }^{147}$, comparative analysis of different leaf proteomes affected by drought stress ${ }^{148,149}$, investigation of the molecular and biochemical mechanisms involved in leaf rust infection ${ }^{150}$, comparative analysis of salinity stress response in salt tolerant and sensitive genotypes ${ }^{151}$, and analysis of enhanced salt tolerance conferred by the mutualistic root fungus Piriformospora indica ${ }^{152}$. These studies have produced a large amount of protein identification information. It is not feasible to discuss individual proteins identified here, but it is possible to make some general observations. The proteins identified in many of these studies are involved with metabolism, which makes sense biochemically, as the imposition of external stressors often has significant effects on the metabolism of plants. Also, many studies involving stress response involve the identification of numerous proteins involved with ROS and oxidative stress. This has also been observed in stress studies in many other plant and animal species.

There have been few studies to date using shotgun proteomics techniques for the identification and quantitation of proteins in barley. This may be reflective of the fact that the barley genome sequencing efforts have been relatively slow when compared to other plants, including other cereal crops. One early paper was published in 2007 using iTRAQ labelling to quantify proteomics changes in different barley varieties displaying different levels of tolerance to boron ${ }^{153}$. Subsequently, there have been several very recent publications using SDS-PAGE gel based shotgun proteomics techniques in some very interesting experiments. One study combined flow cytometry based cell sorting with an SDS-PAGE based shotgun proteomics analysis to provide highly detailed molecular information of high purity barley nuclei ${ }^{154}$. A similar approach was used in another study which identified barley, broom corn millet and bacterial species in artefacts from a 2500 -year-old Chinese archaeological site ${ }^{155}$. A 
similar MS approach was used in combination with in planta ${ }^{15} \mathrm{~N}$ isotope labelling to perform a highly detailed analysis of protein turnover rates in barley leaves, which uncovered significant differences in protein turnover rates associated with important metabolic processes ${ }^{156}$.

Barley has a large haploid genome of 5.1 gigabases. Numerous efforts have been made to sequence the barley genome ${ }^{157}$ but it was only in 2012 that the first functional "whole genome sequence" was made available. This includes a physical map of 4.98 gigabases, with more than 3.90 gigabases anchored to a high resolution genetic map. This sequence information includes survey sequences from a range of diverse cultivars, and displays extensive variation at the single nucleotide level along with abundant alternative splicing, premature termination codons, and novel transcriptionally active regions ${ }^{158}$. This paper was published alongside another that contained data from a very large study of whole genome shotgun sequencing of bread wheat (Triticum aestivum), which reported 454 pyrosequencing of 94,000 to 96,000 wheat genes, producing 17 gigabases of sequence data ${ }^{159}$. Two thirds of those genes were assigned to the three component genomes of hexaploid wheat (A, B and D).

The fact that relatively complete genome sequence information has only became available for barley so recently is obviously important in the proteomics field. It is far more difficult to carry out proteomic investigations on organisms with unsequenced genomes, especially those of a significant size. It is to be hoped that the release of this genome sequence information data will spur an increase in the amount of proteomics work being carried out in barley. A greater understanding of how both wild and cultivated barley plants are able to withstand harsh environmental conditions is essential for the development of enhanced varieties of barley, which promise to be a very important contributor to the continued food security of the human population. 


\section{The Current Status of Proteomics in Soybean}

Soybean is the world's most widely grown seed legume and provides a source of protein and vegetable oil for human consumption. The application of proteomic techniques in dissecting molecular mechanisms has been validated in studies involving various abiotic stresses. This important legume crop has been adapted to grow in a wide range of climatic conditions. However, the growth, development, and yield of soybean are greatly affected by several abiotic stresses, such as flooding (reviewed by ${ }^{160,161}$ ), drought (reviewed by ${ }^{162}$ ), salinity (reviewed by ${ }^{163}$ ), and heavy metal cadmium (reviewed by ${ }^{164}$ ). The information gathered from recent proteomics research (Table 1) has covered all aspects of plant responses including seed germination ${ }^{165}$, the seedling stage ${ }^{166-168}$, the later stages of growth ${ }^{169-170}$, and the seed filling stage ${ }^{171}$. Although these harsh environmental conditions affect soybean plant growth throughout its different developmental stages from seed germination to flowering, the seedling stage is more prone to abiotic stresses, in particular flooding and drought (reviewed by ${ }^{172}$ ). Hossain and Komatsu ${ }^{172}$ inferred that the benefits derived from all of these versatile research approaches can be optimized by integrating the functions and interactions of proteins. The conclusions from this research might be a key for a generalized application of response mechanisms in soybean to other plants as well.

\section{Stage specific proteomics of soybean}

Seed filling is a developmental period when rapid metabolic and morphological changes take place ${ }^{173}$. To better understand the metabolic processes associated with seed filling in soybeans, Agrawal et al. ${ }^{174}$ investigated the seed proteome at five developmental stages using 2-DE and semi-continuous multidimensional protein 
identification technology (Sec-MudPIT) coupled with LC-MS. Comparisons of the quantitative seed-filling proteome of soybean and rapeseed were done to further understand the regulation of intermediary metabolism in protein-rich versus oil-rich seeds. A similar proteomic study was previously performed by Hajduch et al. ${ }^{171}$ to determine the expression profile of soybean seed proteins and the decrease in metabolism-related proteins versus the increase in proteins associated with destination and storage observed during seed filling.

Stress induced changes in the protein profiling of soybeans at the young seedling stage have been well explored. Alam et al. ${ }^{169}$ carried out a proteomic analysis of two weeks old soybean roots exposed to water-logging stress. The 2-DE/MS technique was utilized to separate the proteins. The authors proposed that soybean plants cope with the waterlogged condition through the management of carbohydrate consumption and by regulating programmed cell death. Komatsu et al. ${ }^{175}$ utilized proteomic techniques in combination with transcriptomic techniques to unravel the underlying molecular mechanism conferring flooding tolerance in soybeans. They revealed that proteins related to glycolysis and ROS scavenging were increased in the roots of early stage soybeans exposed to flooding stress ${ }^{176}$.

Drought constitutes another form of water stress that results from a shortage of water. Unlike flooding, drought induces osmotic stress, which affects plant metabolism and yield. Soil salinity is also considered to be one of the environmental constraints that limits the productivity of crop plants including legumes. Previous studies in soybean proteomics have been performed using gel-based proteomic technique. Mohammadi et al. ${ }^{168}$ recently investigated the response of soybean seedlings to drought, suggesting a decrease of methionine synthase, both at mRNA and protein levels, in drought-stressed plants, irrespective of organs. This indicates its possible role in the impairment of 
seedling growth under drought conditions. To elucidate the response of soybean to salt stress, the related changes in protein expressions were investigated using a proteomic approach ${ }^{177}$, and it was determined that the accumulation of metabolism related proteins are mostly affected by salt stress. Sobhanian et al. ${ }^{178}$ indicated that the metabolism of glucose through glycolysis is important to produce the energy required to overcome the salinity stress.

Accumulation of high levels of toxic metals significantly affects soybean growth and development. Although soybean cultivars differ in their ability to take up, accumulate and translocate cadmium to aerial parts, little attention has been paid so far to unravel the underlying molecular mechanism of cadmium tolerance. To understand this mechanism, proteomic techniques have been used ${ }^{167,179}$. Ahsan et al. ${ }^{179}$ investigated differential responses of root microsomal proteins in contrasting cadmium accumulating soybean cultivars exposed to cadmium. Combined proteomic and metabolomic analyses reveal that proteins and amino acids associated with cadmium chelating pathways are highly active in low root-to-shoot cadmium translocating cultivars.

\section{Subcellular proteomics of soybean}

Proteomic analysis of subcellular organelles provides fundamental information about the response of a planned to a given stress at the functional level, and thus refines our knowledge about plant stress related signaling pathways. We recently reviewed plant cell organelle proteomics in response to abiotic stress ${ }^{180}$. A number of subcellular proteomics studies (gel-free or gel based) on soybean have been already reported. Proteomic analyses of the plasma membrane, cell wall, mitochondria, endoplasmic reticulum, and nucleus fractions have been used to investigate the role of 
flooding-responsive proteins in soybean. The results of these analyses suggested that the early response of soybean to flooding is an important stress adaptation that not only ensures survival against hypoxia, but also minimizes direct damage to cells by flooding.

Over all, the scenario of soybean proteomics has started changing since the completion of the soybean draft genome sequence. In spite of being a recalcitrant plant species, protein extraction protocols have been standardized to achieve optimized 2-DE results in terms of protein spot number and spot intensity ${ }^{181}$. Different tissue specific proteomic studies reveal that phenol and tricyclic antidepressant / acetone based extraction protocols are most suitable for soybean protein extraction. Construction of detailed quantitative soybean proteome reference maps facilitates functional genomic studies and also provides an essential tool for the rapid identification of soybean mutants / transgenic lines. Identification of low-abundance proteins has become possible with the development of sensitive stains and rapid technical advancement in MS technology. Proteomic research on soybean response to abiotic stresses. both at the whole plant and organelle levels. provides new insights into stress adaptation. More initiatives need to be taken in order to delineate the molecular basis of acquisition of stress tolerance mechanisms at the organelle level. In depth information about the expression of stress induced novel marker proteins would further enable us to design genetically engineered stress tolerant soybean.

\section{The Current Status of Proteomics in Chickpea}

Chickpea is the second most widely grown legume crop after soybean, accounting for a considerable fraction of human dietary nitrogen intake. It is the third most important food legume crop, with $96 \%$ of the crop cultivated in the developing countries. Currently, chickpea is grown in nearly 27 countries, and 7 countries have an 
annual production of 100,000 tons or more ${ }^{182}$. The Indian subcontinent is the foremost chickpea-producing and -consuming region, contributing about $70 \%$ of the world's total production ${ }^{183}$. It is now known that the global yield growth of chickpea is not only stagnant, but is negatively affected by environmental stresses including abiotic and biotic threats, highlighting the greater need for understanding how plants respond to such stress. The narrow genetic base of cultivated chickpea varieties, and lack of comprehensive intergenic and intragenic molecular marker maps ${ }^{184}$, attenuates the efforts of marker-assisted crop improvement and production of elite cultivars with durable stress-resistance by conventional breeding. This is further compounded by limited genomic and proteomic resources; however, this will be less of a problem in future as the genome sequence of chickpea has recently been published ${ }^{185,186}$. The publicly available tissue specific, development related, and stress responsive transcriptome datasets, including EST resources, micro-array and RNA-seq data ${ }^{187-190}$, along with some gel based proteomic datasets (Table 1), makes this food crop and obvious choice for in-depth proteome analysis. Understanding chickpea biology at a broad scale is an important goal for increasing chickpea production.

It is less than a decade since chickpea proteomic research began its journey. Our recent survey on PubMed (www.pubmed.gov) as of September 2014 indicates that chickpea proteome research is still far behind in the proteomics field. For example, the keywords "legume proteomics" revealed 390 publications, while only 17 publications could be retrieved for the keywords "chickpea proteomics". The current phase is unravelling the chickpea proteomes with 2-DE being a pillar of chickpea proteomics. An in-depth study of chickpea proteomic literature reveals that MS identified about 1936 redundant proteins from different cellular fractions and tissues (Table 1), which is far less than is needed to provide complete proteome coverage. Organ level proteomics 
of chickpea revealed that the maximum numbers of proteins were identified from whole seedling, germinated seeds, and suspension culture. Efforts have been made in chickpea proteomics focusing on the changes in genome expression that are triggered by various environmental factors. A total of 509 proteins have been identified from chickpea under different abiotic stresses. Of these, 489 were involved in dehydration, while 20 proteins were identified under cold stress ${ }^{191-199}$. Organellar proteomics is essential both for complete understanding of organelle function as well as to detect dynamic changes that may occur during various responses. Applications of this methodology to isolate nucleus, extracellular matrix (ECM), and secretory systems have produced insights into the identity and possible function of these organelles (Reviewed by ${ }^{200-202}$ ). These studies identified 91 proteins from total element of the cell, whereas 388 proteins were identified from the ECM, 479 proteins were identified from the nucleus and 91 proteins were identified from the membrane. This area has probably attracted the most research in chickpea proteomics ${ }^{191,193,195,196,203}$. Perhaps unsurprisingly, the nucleus and ECM have been the most thoroughly studied chickpea organellar proteomes. A recent study on chickpea nucleus showed that phosphorylation events have emerged as a powerful foundation to reproducibly enrich organellar phosphoproteomes ${ }^{198}$. A more accurate vision of chickpea subcellular proteomes illustrate that approximately 2,500 organellar proteins from the above-mentioned compartments were identified, indicating that extended organellar proteomics research is required in chickpea.

Chickpea is generally considered to be susceptible to dehydration and cold stress, and dehydration is one of the most severe limitations on the productivity of chickpea ${ }^{204}$. In recent years, two studies on dehydration-responsive nuclear proteomics in chickpea were published ${ }^{192,205}$, which led to the identification of 222 dehydration-responsive nuclear proteins. Two more studies on the chickpea ECM proteome were performed on 
dehydrated seedlings under progressive water loss, and these involve identification of 267 dehydration-responsive ECM proteins. Glycine rich protein, ftsh-like protein, and thioredoxins known to be involved in stress-induced alteration of proteolytic activities were identified as predominant species in the nucleus, whereas kelch repeat-containing F-box family protein, pectinesterase and germin formed the major group in the ECM. To protect the cellular system against stress-induced damage, and to maintain functional protein conformations, a wide range of proteins with chaperone activity like DnaJ and GrpE, that constitutes the KJE (DnaK, DnaJ and GrpE) system, were identified in the differentially expressed chickpea proteome. These proteins were down-regulated in the susceptible chickpea cv. ICCV-2, contrary to their increased expression in the tolerant $\mathrm{cv}$. JG-62. This observation provides the firm foundation for using proteomic approach to study cultivar specific response. Proteome analysis of early responses of chickpea plants to cold stress has also been performed. This investigation led to the identification of only 20 cold stress-responsive proteins, including F box protein, SKP1 protein, thioredoxin and peroxidase. Dynamic protein phosphorylation in chickpea during dehydration stress was examined in one of the most recent reports, indicating that putative signaling proteins were abundant during stress ${ }^{197}$. As part of a functional proteomics initiative, screening of the dehydration- responsive membrane and ECM proteome, led to the identification of a putative SUN (Sad1/UNC-84) protein and a tubby-like protein, designated as CaSUN1 and CaTLP1, respectively. For the first time, a plant SUN protein, CaSUN1 and a plant tubby-like protein, CaTLP1 were primarily characterized in terms of their role in growth and development and in stress-responsive functions 206,207 .

For soybean, chickpea and other legumes, there has also been considerable proteomics research into agriculturally important traits such as seed yield and 
nutritional deficiencies. In a study of sulphur deficiency in the legume Medicago Truncatula (Alfalfa), it was found that sulphur deficiency during the mid-vegetative stage altered the allocation of carbon and nitrogen within the developing seeds, leading to dramatic changes in oligosaccharide accumulation and subsequent germination. In contrast, sulphur deficiency during the reproductive period had little effect on seed yield and nutrient allocation, although the seeds germinated slower than normal ${ }^{208}$. In a related study in Brassica Napus, proteomic analysis was performed on mature seeds collected from plants grown under sulphate limitation, which was applied during different stages of the growing cycle stop the results showed that sulphur limitation caused changes in metabolism which affected lipid quality and seed storage protein composition $^{209}$. In chickpeas, as for other legume species, identifying novel proteins and determining their expression patterns under stress may provide the basis for effective engineering strategies for crop improvement programs.

\section{The Current Status of Proteomics in Vanilla Orchids}

Vanilla orchid is a perennial climbing vine that can grow up to a height of 10-15 $\mathrm{m}$ in subtropical regions. It is an economically important crop due to the natural vanillin which can be extracted from its cured pods. Vanillin is a popular flavour compound that is widely used in a broad range of food based products such as drinks, cookies, cakes and ice cream, as well as in the cosmetics and perfumery industries 210,211 . Currently, natural vanillin only accounts for $1 \%$ of the global production. The remaining $99 \%$ is derived from synthetic vanillin that is chemically produced from fossil fuel or by acid hydrolysis of lignin ${ }^{212}$. In order to cater for the high demand for natural vanillin and the sustainable production of vanillin for future needs, advanced biotechnology tools have been used to boost vanillin production. Even though 
bioconversions using microbials such as Streptomyces setonii, Aspergillus niger and Psuedomonas putida have been carried out, natural vanillin from the vanilla pod is still the most preferred flavouring essence, due to food safety concerns and the growing demand for high quality and minimally processed natural food. Therefore, effort is required to genetically improve the plants and the production of vanillin from the vanilla plants.

There are about 110 species of vanilla plants in the Orchidaceae family ${ }^{213,214}$, of which three are commercially cultivated: Vanilla planifolia Andrews (synonym: V. fragrans); Vanilla pompon Scheide; and Vanilla tahitensis J. W. Moore ${ }^{215}$. Since $V$. planifolia is the most valued for its flavour qualities, it is the most widely cultivated ${ }^{215}$. Conventional propagation of vanilla is carried out using stem cuttings which could lead to a reduction in the growth of the mother plants. This method of propagation is unable to produce sufficient quantities of elite plant materials for cultivation. In addition, extraction of vanillin from the pods of vanilla is costly, laborious and time-consuming. Therefore, there is a need to look for alternative viable methods to circumvent the problems. Thus far, limited work has been done in vanilla orchid on the molecular or cellular mechanisms of the plants. The use of proteomic technology on this plant has also been restricted to the development of the plant in tissue culture and the formation of vanillin in the pods. In this review, we are mainly looking at using proteomic analysis methods to investigate the callus formation in vanilla tissue culture, although proteomic methods have also been used to investigate the formation of vanillin in the vanilla pods (Table 1).

Tissue culture of vanilla plants

One of the promising means of supplying elite planting stocks to expand vanilla 
plantations is to propagate the plants through tissue culture. To date, protocols for micropropagating vanilla in tissue culture have been established in various laboratories 210,216-222. However, the drawback of propagating plants through tissue culture is the low regeneration rate of the explant samples via callus culture. Proteomics technology has been used to investigate the callus formation ${ }^{223}$ and differentiation ${ }^{224}$ in $V$. planifolia. Both researchers used 2-DE coupled with MALDI TOF-TOF MS as their tools of investigation.

Tan et al. ${ }^{223}$ examined the early stage of callus formation from the nodal explants and managed to identify 23 unique proteins related to the processes. Out of these, a majority of the proteins were found to be related to defence and stress response followed by carbohydrate and energy metabolism. Palama et al. ${ }^{224}$ used organogenic callus to investigate the differentiating process of the calli to form shoots. A total of 15 protein spots were found to be significantly expressed at the earlier stages of shoot differentiation. A majority of these proteins are involved in amino acid protein metabolism and photosynthetic activities. Proteomics analysis for tissue culture of vanilla orchids indicated that since callus formation from the explants involves subjecting the cultures to stress conditions, such as exposing the cultures to plant hormones, stress response proteins are produced. Rapid growth and cell division at this stage also required proteins that are involved in metabolic and energy processes. On the other hand, callus differentiation involves cell reprogramming which requires synthesis, assembling and stabilization of proteins. Enzymes involved in the Calvin cycle are also important at the initiation of organogenesis in callus which is related to the photosynthesis processes that are taking place.

Formation of vanillin in the pod 
Elucidation of vanillin biosynthesis pathway is a mammoth task. Gallage et al.

${ }^{225}$ have shown using proteomic analysis in combination with radiolabelled precursors and transcriptomic approaches that a single enzyme designated as vanillin synthase is responsible for catalyzing the direct conversion of ferulic acid and ferulic acid glucoside into vanillin and vanillin glucoside in the inner part of vanilla pods. The proteomic technique used was in-gel digestions of separated proteins coupled with an electrospray ionisation quadrupole TOF MS. these findings have had significant impact on the natural vanilla industries. For example, the accumulation of vanillin glucoside in the pods of the cultivated vanilla vines can now be determined by the use of molecular markers. The use of proteomic analysis complemented with other techniques has shown to be effective in unravel mechanisms underlying important cellular and molecular processes in an important commercial crop such as vanilla orchid.

\section{The Current Status of Proteomics in Palm Fruit}

Phoenix dactylifera, commonly known as the date palm, is a perennial monocot. It is dioecious (with male and female trees), genetically highly diverse ${ }^{226,227}$ and adapted to arid environments. Dates palms continue to be an agriculturally and economically important fruit crop in the Middle East and Northern Africa ${ }^{228}$, valued primarily for the fruit but also for the wood and fibers that are all put to good use. Date fruit are a staple for millions of people ${ }^{229}$, and have potential health benefits due to their high and diverse content of bioactive compounds including polyphenols such as flavonoids and tannins ${ }^{230,231}$. The date industry produced about 7.5 million tons worldwide in 2012 and Saudi Arabia is the third major producer after Egypt and Iran, growing $>400$ cultivars ${ }^{232}$. The two most popular cultivars are 'Sukkary' and 'Barhi' ${ }^{233,234}$. However, productivity is neither regular nor easily predictable, particularly so 
since date production is adversely affected by several biotic stress factors ${ }^{235-237}$. There have been a number of recent reports that have made use of "omics" technologies to study palm biology at the systems level.

Firstly, the draft genome of the Khalas variety lists $>25,000$ gene models covering approximately $90 \%$ of the genes and $60 \%$ of the entire genome ${ }^{238}$. Furthermore, the sequences of eight additional cultivars have identified $>3.5$ million polymorphic sites, including $>10,000$ genic copy number variations. Apart from affording new insight into the genomic organization and diversity of date palms, the draft genome can now serve as a most valuable resource for proteomic approaches. Secondly, several studies have used proteomics to characterize diverse aspects of palm biology (Table 1). Gel-based proteomics technologies were applied to study the "brittle leaf disease" that causes eventual death after a long decline ${ }^{239}$. Proteomic analysis has revealed that the Mn-binding oxygen-evolving enhancer protein 1 and 2, components of the oxygen-evolving complex of photosystem II, were decreased in affected tissue, thereby linking the disease to Mn deficiency. In line with the scope of proteomic systems analyses, the study also allowed inferences to be made about other metabolic and defense processes affected by the impaired function of photosystem II. This study is also a good example of the use of proteomics as a diagnostic tool in plant pathology and a starting point for the development of molecular tools to overcome the problem.

Gel based proteomics coupled with MS has also been used to compare the proteome zygotic and somatic embryos of the date palm (Phoenix dactylifera $\mathrm{L}$. cv. Deglet Nour) ${ }^{240}$. This study resolved qualitative and quantitative differences in the two proteomes and identified 23 differentially accumulated proteins classified into functional categories including glycolysis, citrate cycle, ATP synthesis and carbohydrate biosynthesis. Most of the somatic embryo specific proteins identified 
belonged to glycolysis pathways, whereas those of the zygotic embryo belonged to storage and stress-related proteins. Differentially expressed proteins between both types can give valuable clues to physiological differences between both types of embryos and will inform future approaches to in vitro culture and propagation.

More recently a study on the proteome of the date fruit during development and ripening was reported, revealing proteins classified in 14 functional categories ${ }^{241}$. Interestingly, most proteins were in the categories 'disease and defense' $(16.5 \%)$ and 'metabolism' (15.4\%), which included a number of proteins that have not previously been identified in other fleshy fruits, while 64 showed contrasting expression patterns in other fruits. The abundance of most proteins with a role in abiotic stress responses increased during ripening and proteins with a role in anthocyanin biosynthesis, glycolysis, tricarboxylic acid cycle and cell wall degradation were also up-regulated during ripening, while the expression of pentose phosphate- and photosynthesis-related proteins decreased during maturation. This study suggests that proteomics can indeed provide insights into physiological processes during date fruit development at the systems level and offers a reference proteome for future studies of regulatory mechanisms both in dates and other fleshy fruits.

In the future, it is to be anticipated that additional and more extensive date palm proteome studies will be undertaken, which will contribute to an increased understanding of date biology at the systems level. Also, new proteomics technologies and approaches such as the proteomic analyses of post-translational modifications ${ }^{242}$ will significantly enhance our understanding of regulatory processes in plants. In addition, future studies will also afford new insight into palm defense mechanisms against such devastating pests as the red palm weevil Rhynchophorus ferrugineus ${ }^{243}$ and may contribute to novel pest management strategies ${ }^{244}$. Finally, fruit proteomics 
will not just further our understanding of the role and turnover of proteins and the regulation of pathways during fruit development; it will also support efforts to develop innovative practices for fruit quality improvements.

\section{FUTURE PERSPECTIVE FOR CROP PROTEOMICS IN ASIA AND OCEANIA REGION}

The aim of this review was to discuss the current status and future prospects of food crop proteomics. In the last decade, different laboratories worldwide, including the Asia and Oceania region, were deeply involved in understanding food crop biology using proteomics and mass spectrometric approaches. The technical and data-analysis platforms have been optimized to a large extent. Studies involving mostly 2-DE coupled with MS-based analysis have been performed on a large number of crop proteomes, and this has greatly improved our understanding of the function of proteins during various biological processes, including stress responses. Development of organand organelle- specific proteome maps in different crops has facilitated the comparative study of cultivars, mutants, and transgenics. Proteomics data generated from differential proteomics studies in development and /or stress responses will help to build the foundation for future translational research towards sustainable agriculture. In the early years of the discipline, proteomics analysis was largely a qualitative exercise in developing proteome maps and building the databases of expressed proteins in various tissues, organs and organelles. However, in the past decade great advances have been made in protein fractionation, protein purification, and mass spectrometry, which have enabled faster protein characterization including identification, quantification, localization, and analysis of post-translational modifications and 
protein-protein interactions.

Recently, efforts have also been made to curate be few available plant proteome databases, but none of these databases yet represents the comprehensive and complete collection of the proteins in any crop plant. Further, the number of proteins is surprisingly low considering the number of expected proteins in a cell for any given species. For example, the amount of available proteomic data in rice representing various tissues/organs/organelles, developmental stages, and effect of various external stimuli is small when compared to human proteomics data. The Protein Expression Atlas, to name just one of many examples, has been developed from more than 300 experiments covering shotgun and targeted proteomics approaches. However, the in depth analyses of organ, organellar, and stress-responsive proteins at global level, and their subsequent characterization, are largely unavailable in crop plants. In comparison to the model plant Arabidopsis, the number of publications available on any crop plant in a PubMed search while writing this manuscript (www.pubmed.gov, September, 2014) is much smaller (Figure 1).

Development of analytical methodologies is also challenging in the detection of unintended effects that could be derived during genetic manipulation of crops. With regard to the safety of genetically modified crops and products, the current risk assessment process pays particular attention to potential adverse effects on human and animal health and the environment ${ }^{245}$. Zolla et al. ${ }^{246}$ reported that an exhaustive differential proteomic analysis allowed determination of similarities and differences between traditional food and new products, and a case-by-case assessment of the new food should be carried out in order to obtain greater knowledge of its features. Furthermore, Barros et al. ${ }^{247}$ indicated that environmental factors caused more variation than the difference between genotypes in the different transcript, protein, and 
metabolite profiles. Using gel-based proteomic techniques, Ruebelt et al. ${ }^{248,249}$ addressed the feasibility of using proteomics technology to identify unintended or intended changes in the seed proteins due to genetic engineering. More recently, because gel-free proteomic techniques are in use in many laboratories, such differences should be able to be identified more easily. To improve the probability of detecting unintended side effects during gene manipulations by transgenic techniques, proteomics might be used as an analytical tool complementary to the existing safety assessment techniques.

Attention should be paid to the adoption and application of new methodological approaches for proteomics research, including gel free shotgun proteomics analysis, data independent shot gun proteomics approaches, and targeted proteomics methods, all of which have the high throughput and sensitivity needed to study global changes in protein profiles. In light of the above progress and concerns, the next challenge in the field of crop plant proteomics is, therefore, to characterize the entire complement of the proteome for a given species. A comprehensive proteome analysis (including peptides, small peptides, proteins and missing proteins, isoforms, PTMs) will provide a functional genomics platform for characterizing known and novel proteins and their regulation. The generation of a comprehensive catalogue of protein variants is indeed needed for the discovery of polymorphism and isoforms. Further, genetic architecture of protein expression can be investigated by using protein quantity loci (PQL). This is performed by combining proteomics analysis with established quantitative trait loci (QTL) mapping approaches, and has been shown to be useful in correlating the QTL indicating pleotropic effects in mutants and seed traits ${ }^{250-252}$.

One study using this approach analyzed a large number of recombinant inbred lines of mature pea plants and found that a limited number of loci appeared to control 
accumulation of the major storage protein families ${ }^{252}$. This approach has been applied in other studies which aim to use proteomics as the central linking tool between genetics and physiology. Finding a direct relationship between genetic maps and cellular metabolism is the primary goal of functional genomics, and proteomics is an essential methodology in achieving that aim ${ }^{253}$. Thus, integration of PQL information with QTLs and eQTLs would generate testable new hypotheses based on the existing biological information, and these might link the proteome to the phenome. The discovery of novel protein polymorphisms associated with agronomic traits will be very useful for implementation in molecular breeding approaches.

Most importantly, we are starting to see the emergence of whole genome sequence data, large collections of publicly available transcriptomic datasets including micro-array and RNA-seq, and substantial gel and non-gel based proteomic datasets. The next step will be to integrate the large scale datasets and undertake the systems biology-based approaches needed for the in-depth analysis of protein networks. In addition, interaction proteomics with functional assays should greatly facilitate our understanding of gene function. Taken together, these approaches will not only be useful in identifying regulated signaling pathways and developing biomarkers for abiotic and biotic stresses leading to yield enhancement in agricultural production, but also will aid in identifying potential candidates for improving nutritional quality and optimising food quality and safety. All of these advances will help us along the way to the long-term goal of sustainable continued development of plant-based bioenergy feedstock.

\section{REFERENCES}


(1) Groisman, PY.; Knight, RW.; Easterling, DR.; Karl, TR.; Hegerl, GC.; Razuvaev, VN. Trends in intense precipitation in the climate record. J Clim 2005, 18, 1326-1350.

(2) Komatsu, S.; Haynes, PA.; Salekdeh, GH. Promoting agriculture proteome research activities in the Asia and Oceania region. J. Proteome Res. 2012a, 11, 1461.

(3) Newman, K.; Fisher, S.; Mayhew, S.; Stephenson, J. Population, sexual and reproductive health, rights and sustainable development: forging a common agenda. Reprod. Health Matters 2014, 22, 53-64.

(4) Komatsu, S.; Haynes, PA. Realizing the potential of agricultural and environmental proteomics. J. Proteome Res. 2013, 12, 4651.

(5) Kleffmann, T.; Russenberger, D.; von Zychlinski, A.; Christopher, W.; SjÖlander, K.; Gruissem, W.; Baginsky, S. The Arabidopsis thaliana chloroplast proteome reveals pathway abundance and novel protein functions. Curr. Biol. 2004, 14, $354-362$.

(6) Dunkley, T.P.J.; Hester, S.; Shadforth, I.P.; Runions, J.; Weimar, T.; Hanton, S.L.; Griffin, J.L.; Bessant, C.; Brandizzi, F.; Hawes, C.; Watson, R.B.; Dupree, P.; Lilley, K.S. Mapping the Arabidopsis organelle proteome. Proc. Natl. Acad. Sci. USA 2006, 103, 6518-6523.

(7) Ferro, M.; Salvi, D.; Brugière, S.; Miras, S.; Kowalski, S.; Louwagie, M.; Garin, J.; Joyard, J.; Rolland, N. Proteomics of the chloroplast envelope membranes from Arabidopsis thaliana. Mol. Cell. Proteomics 2003, 2, 325-345.

(8) Gallardo, K.; Job, C.; Groot, SPC.; Puype, M.; Demol, H.; Vandekerckhove, J.; Job, D. Proteomic analysis of Arabidopsis seed germination and priming. Plant Physiol. 2001, 126, 835-848. 
(9) Lindermayr, C.; Saalbach, G.; Durner, J. Proteomic identification of S-nitrosylated proteins in Arabidopsis. Plant Physiol 2005, 137, 921-930.

(10) Sweetlove, L.J.; Heazlewood, J.L.; Herald, V.; Holtzapffel, R.; Day, D.A.; Leaver, C.J.; Millar, A.H. The impact of oxidative stress on Arabidopsis mitochondria. Plant J. 2002, 32, 891-904.

(11) Peltier, J.; Friso, G.; Kalume, D.E.; Roepstorff, P.; Nilsson, F.; Adamska, I.; van Wijk, K.J. Proteomics of the chloroplast: Systematic identification and targeting analysis of lumenal and peripheral thylakoid proteins. Plant Cell 2000, 12, 319-341.

(12) Salekdeh, GH.; Komatsu, S. Crop proteomics: aim at sustainable agriculture of tomorrow. Proteomics 2007, 7, 2976-2996.

(13) Vanderschuren, H., Lentz, E., Zainuddin, I., Gruissem, W. Proteomics of model and crop plant species: Status, current limitations and strategic advances for crop improvement. J. Proteomics 2013, 93, 5-19.

(14) Agrawal, GK.; Sarkar, A.; Righetti, PG.; Pedreschi, R.; Carpentier, S.; Wang, T.; Barkla, BJ.; Kohll, A.; Ndimba, BK.; Bykova, NV.; Rampitsch, C.; Zolla, L.; Rafudeen, MS.; Cramer, R.; Bindschedler, LV.; Tsakirpaloglou, N.; Ndimba, RJ.; Farrant, JM.; Renaut, J.; Job, D.; Kikuchi, S.; Rakwal, R. A decade of plant proteomics and mass spectrometry: Translation of technical advancements to food security and safety issues. Mass Spect. Rev. 2013, 32, 335-365

(15) Lin, Z.; Zhang, X.; Yang, X.; Li, G.; Tang, S.; Wang, S.; Ding, Y.; Liu, Z. Proteomic analysis of proteins related to rice grain chalkiness using ITRAQ and a novel comparison system based on a notched-belly mutant with white-belly. BMC Plant Biol. 2014, 14, 163.

(16) Pascovici, D.; Gardiner, DM.; Song, X.; Breen, E.; Solomon, PS.; Keighley, T.; Molloy, MP. Coverage and consistency: bioinformatics aspects of the analysis of 
multirun iTRAQ experiments with wheat leaves. J. Proteome Res. 2013, 12, $4870-4881$.

(17) International Wheat Genome Sequencing Consortium (IWGSC). A chromosomebased draft sequence of the hexaploid bread wheat (Triticum aestivum) genome. Science 2014, 345, 1251788.

(18) Sasaki, T.; Burr, B. International Rice Genome Sequencing Project: the effort to completely sequence the rice genome. Curr. Opin. Plant Biol. 2000, 3, 138-142.

(19) Goff, SA.; Ricke, D.; Lan, TH.; Presting, G, et al. A draft sequence of the rice genome (Oryza sativa L. ssp. japonica). Science 2002, 296, 92-100.

(20) Yu, J.; Hu, S.; Wang, J.; Wong, GK.; et al. A draft sequence of the rice genome (Oryza sativa L. ssp. indica). Science 2002, 296, 79-92.

(21) Neilson, KA.; George, IS.; Emery, SJ.; Muralidharan, S.; Mirzaei, M.; Haynes, PA. Analysis of rice proteins using SDS-PAGE shotgun proteomics. Methods Mol. Biol. 2014, 1072, 289-302.

(22) Kim, ST.; Kim, SG.; Agrawal, GK.; Kikuchi, S.; Rakwal, R. Rice proteomics: a model system for crop improvement and food security. Proteomics 2014, 14, 593-610.

(23) He, D.; Yang, P. Proteomics of rice seed germination. Front. Plant Sci. 2013, 4 , 246.

(24) Han, C.; Yang, P.; Sakata, K.; Komatsu, S. Quantitative proteomics reveals the role of protein phosphorylation in rice embryos during early stages of germination. J. Proteome Res. 2014a, 13, 1766-1782.

(25) Han, C.; Wang, K.; Yang, P. Gel-based comparative phosphoproteomic analysis on rice embryo during germination. Plant Cell Physiol. 2014b, 55, 1376-1394.

(26) Han, C.; He, D.; Li, M.; Yang, P. In-depth proteomic analysis of rice embryo 
reveals its important roles in seed germination. Plant Cell Physiol. 2014c, 55, 1826-1847.

(27) He, D.; Han, C.; Yang, P. Gene expression profile changes in germinating Rice. J. Integr. Plant Biol. 2011, 53, 835-844.

(28) Kim, ST.; Kang, SY.; Wang, Y.; Kim, SG.; et al. Analysis of embryonic proteome modulation by GA and ABA from germinating rice seeds. Proteomics 2008, 8 , $3577-3587$.

(29) Yang, P.; Chen, H.; Liang, Y.; Shen, S. Proteomic analysis of de-etiolated rice seedlings upon exposure to light. Proteomics 2007, 7, 2459-2468.

(30) Hwang, H.; Cho, MH.; Hahn, BS.; Lim, H.; Kwon, YK.; Hahn, TR.; Bhoo, SH. Proteomic identification of rhythmic proteins in rice seedlings. Biochim. Biophys. Acta 2011, 1814, 470-479.

(31) Wang, Z.; Wang, T. Dynamic proteomic analysis reveals diurnal homeostasis of key pathways in rice leaves. Proteomics 2011, 11, 225-238.

(32) Nozu, Y.; Tsugita, A.; Kamijo, K. Proteomic analysis of rice leaf, stem and root tissues during growth course. Proteomics 2006, 6, 3665-3670.

(33) Yang, P.; Liang, Y.; Shen, S.; Kuang, T. Proteome analysis of rice uppermost internodes at the milky stage. Proteomics 2006, 6, 3330-3338.

(34) Abiko, M.; Furuta, K.; Yamauchi, Y.; Fujita, C.; Taoka, M.; Isobe, T.; Okamoto, T. Identification of proteins enriched in rice egg or sperm cells by single-cell proteomics. PLoS One 2013, 8, e69578.

(35) Kerim, T.; Imin, N.; Weinman, JJ.; Rolfe, BG. Proteome analysis of male gametophyte development in rice anthers. Proteomics 2003, 3, 738-751.

(36) Sarhadi, E.; Bazargani, MM.; Sajise, AG.; Abdolahi, S.; Vispo, NA.; Arceta, M, Nejad, GM, Singh, RK, Salekdeh, GH. Proteomic analysis of rice anthers under 
salt stress. Plant Physiol. Biochem. 2012, 58, 280-287.

(37) Sun, Q.; Hu, C.; Hu, J.; Li, S.; Zhu, Y. Quantitative proteomic analysis of CMS-related changes in Honglian CMS rice anther. Protein J. 2009, 28, 341-348.

(38) Yan, J.; Tian, H.; Wang, S.; Shao, J.; Zheng, Y.; Zhang, H.; Guo, L.; Ding, Y. Pollen developmental defects in ZD-CMS rice line explored by cytological, molecular and proteomic approaches. J. Proteomics 2014, 108, 110-123.

(39) Wang, K.; Zhao, Y.; Li, M.; Gao, F.; Yang, MK.; Wang, X.; Li, S.; Yang, P. Analysis of phosphoproteome in rice pistil. Proteomics 2014, 14, 2319-1319.

(40) Xu, SB.; Li, T.; Deng, ZY.; Chong, K.; Xue, Y.; Wang, T. Dynamic proteomic analysis reveals a switch between central carbon metabolism and alcoholic fermentation in rice filling grains. Plant Physiol. 2008a, 148, 908-925.

(41) Xu, H.; Zhang, W.; Gao, Y.; Zhao, Y.; Guo, L.; Wang, J. Proteomic analysis of embryo development in rice (Oryza sativa). Planta 2012, 235, 687-701.

(42) Zi, J.; Zhang, J.; Wang, Q.; Lin, L.; Tong, W.; Bai, X.; Zhao, J.; Chen, Z.; Fu, X.; Liu, S. Proteomics study of rice embryogenesis: discovery of the embryogenesisdependent globulins. Electrophoresis 2012, 33, 1129-1138.

(43) Yu, HT.; Xu, SB.; Zheng, CH.; Wang, T. Comparative proteomic study reveals the involvement of diurnal cycle in cell division, enlargement, and starch accumulation in developing endosperm of Oryza sativa. J. Proteome Res. 2012, 11, $359-371$.

(44) Singh, R.; Jwa, NS. Understanding the responses of rice to environmental stress using proteomics. J. Proteome Res. 2013, 12, 4652-469.

(45) Nwugo, CC.; Huerta, AJ. The effect of silicon on the leaf proteome of rice (Oryza sativa L.) plants under cadmium-stress. J. Proteome Res. 2011, 10, 518-528.

(46) Liu, Y.; Li, M.; Han, C.; Wu, F.; Tu, B.; Yang, P. Comparative proteomic analysis 
of rice shoots exposed to high arsenate. J. Integr. Plant Biol. 2013, 55:965-78.

(47) Neilson, KA.; Mariani, M.; Haynes, PA. Quantitative proteomic analysis of coldresponsive proteins in rice. Proteomics 2011, 11, 1696-706.

(48) Neilson, KA.; Scafaro, AP.; Chick, JM.; George, IS.; et al. The influence of signals from chilled roots on the proteome of shoot tissues in rice seedlings. Proteomics 2013, 13, 1922-33.

(49) Jagadish, SV.; Muthurajan, R.; Oane, R.; Wheeler, TR.; Heuer, S.; Bennett, J.; Craufurd, PQ. Physiological and proteomic approaches to address heat tolerance during anthesis in rice (Oryza sativa L.). J. Exp. Bot. 2010, 61, 143-156.

(50) Kawano, Y.; Shimamoto, K. Early signaling network in rice PRR-mediated and R-mediated immunity. Curr. Opin. Plant Biol. 2013, 16, 496-504.

(51) Wang, Y.; Wu, J.; Park, ZY.; Kim, SG.; et al. Comparative secretome investigation of Magnaporthe oryzae proteins responsive to nitrogen starvation. J. Proteome Res. 2011a, 10, 3136-3148.

(52) Jung, YH.; Jeong, SH.; Kim, SH.; Singh, R.; et al. Secretome analysis of Magnaporthe oryzae using in vitro systems. Proteomics 2012, 12, 878-900.

(53) Kim, SG.; Wang, Y.; Lee, KH.; Park, ZY.; et al. In-depth insight into in vivo apoplastic secretome of rice Magnaporthe oryzae interaction. J. Proteomics 2013, $78,58-71$.

(54) Gonzalez, JF.; Degrassi, G.; Devescovi, G.; De Vleesschauwer, D.; et al. A proteomic study of Xanthomonas oryzae pv. oryzae in rice xylem sap. J. Proteomics 2012, 75, 5911-5919.

(55) Wang, Y.; Kim, SG.; Wu, J.; Huh, HH.; et al. Secretome analysis of the rice bacterium Xanthomonas oryzae using in vitro and in planta systems. Proteomics 2013, 13, 1901-1912. 
(56) Wei, Z.; Hu, W.; Lin, Q.; Cheng, X.; et al. Understanding rice plant resistance to the Brown Planthopper (Nilaparvata lugens): a proteomic approach. Proteomics 2009, 9, 2798-2808.

(57) Zhai, Y.; Zhang, J.; Sun, Z.; Dong, X.; et al. Proteomic and transcriptomic analyses of fecundity in the brown planthopper Nilaparvata lugens (Stål). J. Proteome Res. 2013, 12, 5199-212.

(58) FAOSTAT. Statistical databases and data-sets of the Food and Agriculture Organization of the United Nations. http://faostat.fao.org/default.aspx. Accessed April 2010.

(59) Shiferaw, B.; Prasanna, BM.; Hellin, J.; Bänziger, M. Crops that feed the world 6. Past successes and future challenges to the role played by maize in global food security. Food Security 2011, 3, 307-327.

(60) Schnable, PS.; Ware, D.; Fulton, RS.; Stein, JC.; Wei, F.; Pasternak, S.; Liang, C.; Zhang, J.; Fulton, L.; Graves, TA. The B73 maize genome: complexity, diversity, and dynamics. Science 2009, 326, 1112-1115.

(61) Pechanova, O.; Takáč , T.; Šamaj, J.; Pechan, T. Maize proteomics: an insight into the biology of an important cereal crop. Proteomics 2013, 13, 637-662.

(62) Nestler, J.; Schütz, W.; Hochholdinger, F. Conserved and unique features of the maize (Zea mays L.) root hair proteome. J. Proteome Res. 2011, 10, 2525-2537.

(63) Yu, J.; Roy, SK.; Kamal, AHM.; Cho, K.; Kwon, S-J.; Cho, S-W.; So, Y-S.; Holland, JB.; Woo, SH. Protein profiling reveals novel proteins in pollen and pistil of W22 (ga1; Ga1) in maize. Proteomes 2014, 2, 258-271.

(64) Wu, X.; Cai, G.; Gong, F.; An, S.; Cresti, M.; Wang, W. Proteome profiling of maize pollen coats reveals novel protein components. Plant Mol. Biol. Rep. 2014, $1-12$. 
(65) Guo, B.; Chen, Y.; Li, C.; Wang, T.; Wang, R.; Wang, B.; Hu, S.; Du, X.; Xing, H.; Song, X. Maize (Zea mays L.) seedling leaf nuclear proteome and differentially expressed proteins between a hybrid and its parental lines. Proteomics 2014, 14, 1071-1087.

(66) Jin, X.; Fu, Z.; Ding, D.; Li, W.; Liu, Z.; Tang, J. Proteomic identification of genes associated with maize grain-filling rate. PloS One 2013a, 8, e59353.

(67) Pinheiro, C.; Sergeant, K.; Machado, CM.; Renaut, J.; Ricardo, CP. Two traditional maize inbred lines of contrasting technological abilities are discriminated by the seed flour proteome. J. Proteome Res. 2013, 12, 3152-3165.

(68) Guo, B.; Chen, Y.; Zhang, G.; Xing, J.; Hu, Z.; Feng, W.; Yao, Y.; Peng, H.; Du, J.; Zhang, Y. Comparative proteomic analysis of embryos between a maize hybrid and its parental lines during early stages of seed germination. PloS One 2013, 8, e65867.

(69) Uváčková, L'; Takáč, T.; Boehm, N.; Obert, B.; Šamaj, J. Proteomic and biochemical analysis of maize anthers after cold pretreatment and induction of androgenesis reveals an important role of anti-oxidative enzymes. J. Proteomics 2012, 75, 1886-1894.

(70) Zörb, C.; Herbst, R.; Forreiter, C.; Schubert, S. Short - term effects of salt exposure on the maize chloroplast protein pattern. Proteomics 2009, 9, 4209-4220.

(71) Zörb, C.; Schmitt, S.; Mühling, KH. Proteomic changes in maize roots after short - term adjustment to saline growth conditions. Proteomics 2010, 10, $4441-4449$.

(72) Bai, X.; Yang, L.; Yang, Y.; Ahmad, P.; Yang, Y.; Hu, X. Deciphering the protective role of nitric oxide against salt stress at thephysiological and proteomic levels in maize. J. Proteome Res. 2011, 10, 4349-4364. 
(73) Meng, L-B.; Chen, Y-B.; Lu, T-C.; Wang, Y-F.; Qian, C-R.; Yu, Y.; Ge, X-L.; Li, X-H.; Wang, B-C. A systematic proteomic analysis of NaCl-stressed germinating maize seeds. Mol. Biol. Rep. 2014, 41, 3431-3443.

(74) Alvarez, S.; Choudhury, SR.; Pandey, S. Comparative quantitative proteomics analysis of the aba response of roots of drought-sensitive and drought-tolerant wheat varieties identifies proteomic signatures of drought adaptability. J. Proteome Res. 2014, 13, 1688-1701.

(75) Huang, H.; Møller, IM.; Song, S-Q. Proteomics of desiccation tolerance during development and germination of maize embryos. J. Proteomics 2012, 75, 1247-1262.

(76) Zhu, J.; Alvarez, S.; Marsh, EL.; LeNoble, ME.; Cho, I-J.; Sivaguru, M.; Chen, S.; Nguyen, HT.; Wu, Y.; Schachtman, DP. Cell wall proteome in the maize primary root elongation zone. II. Region-specific changes in water soluble and lightly ionically bound proteins under water deficit. Plant Physiol. 2007, 145, 1533-1548.

(77) Li, K.; Xu, C.; Zhang, K.; Yang, A.; Zhang J. Proteomic analysis of roots growth and metabolic changes under phosphorus deficit in maize (Zea mays L.) plants. Proteomics 2007, 7, 1501-1512.

(78) Wu, L.; Wang, S.; Chen, X.; Wang, X.; Wu, L.; Zu, X.; Chen, Y. Proteomic and phytohormone analysis of the response of maize (Zea mays L.) Seedlings to sugarcane mosaic virus. PloS One 2013a, 8, e70295.

(79) Chen, Y.; Chen, X.; Wang, H.; Bao, Y.; Zhang, W. Examination of the leaf proteome during flooding stress and the induction of programmed cell death in maize. Proteome Sci. 2014, 12, 33.

(80) Wu, L.; Zu, X.; Wang, X.; Sun, A.; Zhang, J.; Wang, S.; Chen, Y. Comparative proteomic analysis of the effects of salicylic acid and abscisicacid on maize (Zea 
mays L.) leaves. Plant Mol. Biol. Rep. 2013b, 31, 507-516.

(81) Majeran, W.; Friso, G.; Ponnala, L.; Connolly, B.; Huang, M.; Reidel, E.; Zhang, C.; Asakura, Y.; Bhuiyan, NH.; Sun, Q. Structural and metabolic transitions of C4 leaf development and differentiation defined by microscopy and quantitative proteomics in maize. Plant Cell 2010, 22, 3509-3542.

(82) Friso, G.; Majeran, W.; Huang, M.; Sun, Q.; Van Wijk, KJ. Reconstruction of metabolic pathways, protein expression, and homeostasis machineries across maize bundle sheath and mesophyll chloroplasts: large-scale quantitative proteomics using the first maize genome assembly. Plant Physiol. 2010, 152, 1219-1250.

(83) Majeran, W.; Friso, G.; Asakura, Y.; Qu, X.; Huang, M.; Ponnala, L.; Watkins, KP.; Barkan, A.; Van Wijk, KJ. Nucleoid-enriched proteomes in developing plastids and chloroplasts from maize leaves: a new conceptual framework for nucleoid functions. Plant physiol. 2012, 158, 156-189.

(84) Walley, JW.; Shen, Z.; Sartor, R.; Wu, KJ.; Osborn, J.; Smith, LG.; Briggs, SP. Reconstruction of protein networks from an atlas of maize seed proteotypes. Proc. Natl. Acad. Sci. USA 2013, 110, E4808-E4817.

(85) Facette, M. R.; Shen, Z.; Bjornsdottir, F. R.; Briggs, S. P.; Smith, L. G. Parallel proteomic and phosphoproteomic analyses ofsuccessive stages of maize leaf development. Plant Cell 2013, 25, 2798-2812.

(86) Castellana, N.; Bafna, V. Proteogenomics to discover the full coding content of genomes: a computational perspective. J. proteomics 2010, 73, 2124-2135.

(87) Castellana, NE.; Shen, Z.; He, Y.; Walley, JW.; Briggs, SP.; Bafna, V. An automated proteogenomic method uses mass spectrometry to reveal novel genes in Zea mays. Mol. Cell. Proteomics 2014, 13, 157-167.

(88) Peng, Z.; Wang, M.; Li, F.; Lv, H.; Li, C.; Xia, G. A proteomic study of the 
response to salinity and drought stress in an introgression strain of bread wheat. Mol. Cell. Proteomics 2009, 8, 2676-2686.

(89) Peremarti, A.; Mare, C.; Aprile, A.; Roncaglia, E.; Cattivelli, L.; Villegas, D.; Royo, C. Transcriptomic and proteomic analyses of a pale-green durum wheat mutant shows variations in photosystem components and metabolic deficiencies under drought stress. BMC Genomics 2014, 15, 125.

(90) Guo, G.; Lv, D.; Yan, X.; Subburaj, S.; Ge, P.; Li, X.; Hu, Y.; Yan, Y. Proteome characterization of developing grains in bread wheat cultivars (Triticum aestivum L.). BMC Plant Biol. 2012a, 12, 147.

(91) Jacoby, RP.; Millar, AH.; Taylor, NL. Wheat mitochondrial proteomes provide new links between antioxidant defense and plant salinity tolerance. J. Proteome Res. 2010, 9, 6595-6604.

(92) Laino, P.; Shelton, D.; Finnie, C.; De Leonardis, AM.; Mastrangelo, AM.; Svensson, B.; Lafiandra, D.; Masci, S. Comparative proteome analysis of metabolic proteins from seeds of durum wheat (cv. Svevo) subjected to heat stress. Proteomics 2010, 10, 2359-2368.

(93) Tester, M.; Langridge, P. Breeding technologies to increase crop production in a changing world. Science 2010, 327, 818-822.

(94) Boyer, JS. Plant productivity and environment. Science 1982, 218:443-448.

(95) Bazargani, MM.; Sarhadi, E.; Bushehri, AA.; Matros, A.; Mock, HP.; Naghavi, MR.; Hajihoseini, V.; Mardi, M.; Hajirezaei, MR.; Moradi, F.; Ehdaie, B.; Salekdeh, GH. A proteomics view on the role of drought-induced senescence and oxidative stress defense in enhanced stem reserves remobilization in wheat. J. Proteomics 2011, 74, 1959-1973.

(96) Demirevska, K.; Zasheva, D.; Dimitrov, R.; Simova-Stoilova, L.; Stamenova, M.; 
Feller, U. Drought stress effects on rubisco in wheat: changes in the rubisco large subunit. Acta Physiol. Plant 2009, 31, 1129-1138.

(97) Majoul, T.; Bancel, E.; Triboi, E.; Ben, HJ.; Branlard, G. Proteomic analysis of the effect of heat stress on hexaploid wheat grain: characterization of heat responsive proteins from non - prolamins fraction. Proteomics 2004, 4, 505-513.

(98) Yang, F.; Jorgensen, AD.; Li, H.; Sondergaard, I.; Finnie, C.; Svensson, B.; Jiang, D.; Wollenweber, B.; Jacobsen, S. Implications of high - temperature events and water deficits on protein profiles in wheat (Triticum aestivum L. cv. Vinjett) grain. Proteomics 2011, 11, 1684-1695.

(99) Vitamvas, P.; Prasil, IT.; Kosova, K.; Planchon, S.; Renaut, J. Analysis of proteome and frost tolerance in chromosome $5 \mathrm{~A}$ and $5 \mathrm{~B}$ reciprocal substitution lines between two winter wheats during long - term cold acclimation. Proteomics 2012, $12,68-85$.

(100) Capriotti, AL.; Borrelli, GM.; Colapicchioni, V.; Papa, R.; Piovesana, S.; Samperi, R.; Stampachiacchiere, S.; Lagana, A. Proteomic study of a tolerant genotype of durum wheat under salt-stress conditions. Anal. Bioanal. Chem. 2014, 406, 1423-1435.

(101) Guo, G.; Ge, P.; Ma, C.; Li, X.; Lv, D.; Wang, S.; Ma, W.; Yan, Y. Comparative proteomic analysis of salt response proteins in seedling roots of two wheat varieties. J. Proteomics 2012b, 75, 1867-1885.

(102) Gao, L.; Yan, X.; Li, X.; Guo, G.; Hu, Y.; Ma, W.; Yan, Y. Proteome analysis of wheat leaf under salt stress by two-dimensional difference gel electrophoresis (2D-DIGE). Phytochemistry 2011, 72, 1180-1191.

(103) Guo, H.; Zhang, H.; Li, Y.; Ren, J.; Wang, X.; Niu, H.; Yin J. Identification of changes in wheat (Triticum aestivum L.) seeds proteome in Response to Anti-trx s 
Gene. PLoS One 2011, 6, e22255.

(104) Majoul, T.; Bancel, E.; Triboï, E.; Ben Hamida, J.; Branlard, G. Proteomic analysis of the effect of heat stress on hexaploid wheat grain characterization of heat - responsive proteins from total endosperm. Proteomics 2003, 3, 175-183.

(105) Kang, G.; Li, G.; Xu, W.; Peng, X.; Han, Q.; Zhu, Y.; Guo, T. Proteomics reveals the effects of salicylic acid on growth and tolerance to subsequent drought stress in wheat. J. Proteome Res. 2012, 11, 6066-6079.

(106) Caruso, G.; Cavaliere, C.; Foglia, P.; Gubbiotti, R.; Samperi, R.; Lagana, A. Analysis of drought responsive proteins in wheat (Triticum durum) by 2D-PAGE and MALDI-TOF mass spectrometry. Plant Sci. 2009, 177, 570-576.

(107) Ford, KL.; Cassin, A.; Bacic, A. Quantitative proteomic analysis of wheat cultivars with differing drought stress tolerance. Front. Plant Sci. 2011, 2, 44.

(108) Zhang, S.; Song, G.; Li, Y, Gao, J.; Wang, J.; Chen, G.; Li, H.; Li, G.; Zhao, Z. Comparative proteomic analysis of cold responsive proteins in two wheat cultivars with different tolerance to spring radiation frost. Front. Agr. Sci. Eng. 2014, 1, 37-45.

(109) Jiang, SS.; Liang, XN.; Li, X.; Wang, SL.; Lv, DW.; Ma, CY.; Li, XH.; Ma, WJ.; Yan, YM. Wheat drought-responsive grain proteome analysis by linear and nonlinear 2-DE and MALDI-TOF mass spectrometry. Int. J. Mol. Sci. 2012, 13, 16065-16083.

(110) Ge, P.; Ma, C.; Wang, S.; Gao, L.; Li, X.; Guo, G.; Ma, W.; Yan, Y. Comparative proteomic analysis of grain development in two spring wheat varieties under drought stress. Anal. Bioanal. Chem. 2012, 402, 1297-1313.

(111) Budak, H.; Akpinar, BA.; Unver, T.; Turktas, M. Proteome changes in wild and modern wheat leaves upon drought stress by two-dimensional electrophoresis and 
nanoLC-ESI-MS/MS. Plant Mol. Biol. 2013, 83, 89-103.

(112) Caruso, G.; Cavaliere, C.; Guarino, C.; Gubbiotti, R.; Foglia, P.; Lagana, A. Identification of changes in (Triticum durum L.) leaf proteome in response to salt stress by two-dimensional electrophoresis and MALDI-TOF mass spectrometry. Anal. Bioanal. Chem. 2008, 391, 381-390.

(113) Maleki, M.; Naghavi, MR.; Alizadeh, H.; Poostini, K.; Mishani, CA. Comparison of protein changes in the leaves of two bread wheat cultivars with different sensitivity under salt stress. Ann. Res. Rev. Biol. 2014, 4, 1784-1797.

(114) Fercha, A.; Capriotti, AL.; Caruso, G.; Cavaliere, C.; Gherroucha, H.; Samperi, R.; Stampachiacchiere, S.; Lagana, A. Gel-free proteomics reveal potential biomarkers of priming-induced salt tolerance in durum wheat. J. Proteomics 2013, 91, 486-499.

(115) Sarhadi, E.; Mahfoozi, S.; Hosseini, SA.; Salekdeh, GH. Cold acclimation proteome analysis reveals close link between the up-regulation of low-temperature associated proteins and vernalization fulfillment. J. Proteome Res. 2010, 9, $5658-5667$.

(116) Rinalducci, S.; Egidi, MG.; Karimzadeh, G.; Jazii, FR.; Zolla, L. Proteomic analysis of a spring wheat cultivar in response to prolonged cold stress. Electrophoresis 2011, 32, 1807-1818.

(117) Han, Q.; Kang, G.; Guo, T. Proteomic analysis of spring freeze-stress responsive proteins in leaves of bread wheat (Triticum aestivum L.). Plant Physiol. Biochem. 2013, 63, 236-244.

(118) Kosova, K.; Prasil, IT.; Vitamvas, P.; Dobrev, P.; Motyka, V.; Flokova, K.; Novak, O. Complex phytohormone responses during the cold acclimation of two wheat cultivars differing in cold tolerance, winter Samanta and spring Sandra. J. Plant 
Physiol. 2012, 169, 567-576.

(119) Zheng, YS.; Guo, JX.; Zhang, JP.; Gao, AN.; Yang, XM.; Li, XQ.; Liu, WH.; Li, LH. A proteomic study of spike development inhibition in bread wheat.

Proteomics 2013, 13, 2622-2637.

(120) Kim, KH.; Mostafa Kamal AH.; Shin, KH.;Choi, JS.; Heo, HY.; Woo, SH.

Large-scale proteome investigation in wild relatives (A, B, and D genomes) of wheat. Acta Biochim. Biophys. Sin. 2010, 42, 709-716.

(121) Vensel, WH.; Tanaka, CK.; Cai, N.; Wong, JH.; Buchanan, BB.; Hurkman, WJ.

Developmental changes in the metabolic protein profiles of wheat endosperm.

Proteomics 2005, 5, 1594-1611.

(122) Kamal, AHM.; Kim, KH.; Shin, DH.; Seo, HS.; Shin, KH.; Park, CS.; Heo, HY; Woo, SH. Proteomics profile of pre-harvest sprouting wheat by using MALDI-TOF mass spectrometry. Plant Omics J. 2009, 2, 110-119.

(123) Mamone, G.; De, CS.; Di, LA.; Addeo, F.; Ferranti, P. Proteomic - based analytical approach for the characterization of glutenin subunits in durum wheat. J. Mass Spectrom. 2009, 44, 17.

(124) Gao, L.; Wang, A.; Li, X.; Dong, K.; Wang, K, Appels, R, Ma, W, Yan, Y. Wheat quality related differential expressions of albumins and globulins revealed by two-dimensional difference gel electrophoresis (2-D DIGE). J. Proteomics 2009, $73,279-296$

(125) Nadaud, I.; Girousse, C.; Debiton, C.; Chambon, C.; Bouzidi, MF.; Martre, P.; Branlard, G. Proteomic and morphological analysis of early stages of wheat grain development. Proteomics 2010, 10, 2901-2910.

(126) Tasleem-Tahir, A.; Nadaud, I.; Girousse, C.; Martre, P.; Marion, D.; Branlard, G. Proteomic analysis of peripheral layers during wheat (Triticum aestivum L.) grain 
development. Proteomics 2011, 11, 371-379.

(127) Liu, W.; Zhang, Y.; Gao, X.; Wang, K.; Wang, S.; Zhang, Y.; He, Z.; Ma, W.; Yan, Y. Comparative proteome analysis of glutenin synthesis and accumulation in developing grains between superior and poor quality bread wheat cultivars. J. Sci. Food Agric. 2012, 92, 106-115.

(128) Pompa, M.; Giuliani, MM.; Palermo, C.; Agriesti, F.; Centonze, D.; Flagella, Z. Comparative analysis of gluten proteins in three durum wheat cultivars by a proteomic approach. J. Agric. Food Chem. 2013, 61, 2606-2617.

(129) Irar, S.; Brini, F.; Goday, A.; Masmoudi, K.; Pages, M. Proteomic analysis of wheat embryos with 2-DE and liquid-phase chromatography (ProteomeLab PF-2D)-a wider perspective of the proteome. J. Proteomics 2010, 73, 1707-1721.

(130) Vensel, WH.; Tanaka, CK.; Altenbach SB. Protein composition of wheat gluten polymer fractions determined by quantitative two-dimensional gel electrophoresis and tandem mass spectrometry. Proteome Sci. 2014, 12, 8.

(131) Duan, J.; Tian, X.; Jia, Z. Proteomics uncovers a role for enhanced ultraviolet-b radiation on wheat leaves. Am. J. Plant Sci. 2013, 4, 1227-1232.

(132) Wang, Y.; Qian, Y.; Hu, H.; Xu, Y.; Zhang, H. Comparative proteomic analysis of Cd-responsive proteins in wheat roots. Acta Physiol. Plant 2011b, 33, 349-357.

(133) Oh, MW.; Roy, SK.; Kamal, AH.; Cho, K.; Cho, SW.; Park, CS.; Choi, JS.; Komatsu, S.; Woo, SH. Proteome analysis of roots of wheat seedlings under aluminum stress. Mol. Biol. Rep. 2014, 41, 671-681.

(134) Li, G.; Peng, X.; Xuan, H.; Wei, L.; Yang, Y.; Guo, T.; Kang, G. Proteomic analysis of leaves and roots of common wheat (Triticum aestivum 1.) under copper-stress conditions. J. Proteome Res. 2013, 12, 4846-4861.

(135) Alvarez, S.; Marsh, EL.; Schroeder, SG.; Schachtman, DP. Metabolomic and 
proteomic changes in the xylem sap of maize under drought. Plant Cell Environ. 2008, 31, 325-340.

(136) Kong, FJ.; Oyanagi, A.; Komatsu, S. Cell wall proteome of wheat roots under flooding stress using gel-based and LC MS/MS-based proteomics approaches. Biochim. Biophys. Acta 2010, 1804, 124-136.

(137) Kang, G.; Li, G.; Ma, H.; Wang, C.; Guo, T. Proteomic analysis on the leaves of TaBTF3 gene virus-induced silenced wheat plants may reveal its regulatory mechanism. J. Proteomics 2013, 83, 130-143.

(138) Nevo, E.; Fu, YB.; Pavlicek, T.; Khalifa, S.; et al. Evolution of wild cereals during 28 years of global warming in Israel. Proc. Natl. Acad. Sci. USA 2012, 109, $3412-3415$.

(139) McCouch, S.; Baute, G. J.; Bradeen, J.; Bramel, P.; et al. Agriculture: Feeding the future. Nature 2013, 499, 23-24.

(140) Purugganan, MD.; Fuller, DQ. The nature of selection during plant domestication. Nature 2009, 457, 843-848.

(141) Collins, H. M.; Burton, R. A.; Topping, D. L.; Liao, M.; et al. Variability in fine structures of noncellulosic cell wall polysaccharides from cereal grains: potential importance in human health and nutrition. Cereal Chem. 2010, 87, 272-282.

(142) Finnie, C.; Svensson, B. Barley seed proteomics from spots to structures. J. Proteomics 2009, 72, 315-324.

(143] Sule, A.; Vanrobaeys, F.; Hajos, G.; Van Beeumen, J.; Devreese, B. Proteomic analysis of small heat shock protein isoforms in barley shoots. Phytochemistry 2004, 65, 1853-1863.

(144) March, TJ.; Richter, D.; Colby, T.; Harzen, A.; et al. Identification of proteins associated with malting quality in a subset of wild barley introgression lines. 
Proteomics 2012, 12, 2843-2851.

(145) Moller, AL.; Pedas, P.; Andersen, B.; Svensson, B.; et al. Responses of barley root and shoot proteomes to long-term nitrogen deficiency, short-term nitrogen starvation and ammonium. Plant Cell Environ. 2011, 34, 2024-2037.

(146) Bonsager, B. C.; Finnie, C.; Roepstorff, P.; Svensson, B. Spatio-temporal changes in germination and radical elongation of barley seeds tracked by proteome analysis of dissected embryo, aleurone layer, and endosperm tissues. Proteomics 2007, 7, 4528-4540.

(147) Sun, H.; Cao, F.; Wang, N.; Zhang, M.; et al. Differences in grain ultrastructure, phytochemical and proteomic profiles between the two contrasting grain Cd-accumulation barley genotypes. PLoS One 2013, 8, e79158.

(148) Ashoub, A.; Beckhaus, T.; Berberich, T.; Karas, M.; Bruggemann, W., Comparative analysis of barley leaf proteome as affected by drought stress. Planta 2013, 237, 771-781.

(149) Kausar, R.; Arshad, M.; Shahzad, A.; Komatsu, S. Proteomics analysis of sensitive and tolerant barley genotypes under drought stress. Amino Acids 2013, $44,345-359$.

(150) Bernardo, L.; Prinsi, B.; Negri, A. S.; Cattivelli, L.; et al. Proteomic characterization of the Rph15 barley resistance gene-mediated defence responses to leaf rust. BMC Genomics 2012, 13, 642 .

(151) Rasoulnia, A.; Bihamta, MR.; Peyghambari, SA.; Alizadeh, H.; Rahnama, A. Proteomic response of barley leaves to salinity. Mol. Biol. Rep. 2011, 38, $5055-5063$.

(152) Alikhani, M.; Khatabi, B.; Sepehri, M.; Nekouei, MK.; et al. A proteomics approach to study the molecular basis of enhanced salt tolerance in barley 
(Hordeum vulgare L.) conferred by the root mutualistic fungus Piriformospora indica. Mol. Biosyst 2013, 9, 1498-1510.

(153) Patterson, J.; Ford, K.; Cassin, A.; Natera, S.; Bacic, A. Increased abundance of proteins involved in phytosiderophore production in boron-tolerant barley. Plant Physiol. 2007, 144, 1612-1631.

(154) Petrovska, B.; Jerabkova, H.; Chamrad, I.; Vrana, J.; et al. Proteomic analysis of barley cell nuclei purified by flow sorting. Cytogenet Genome Res. 2014, 143, $78-86$.

(155) Shevchenko, A.; Yang, Y, Knaust, A.; Thomas, H.; et al. Proteomics identifies the composition and manufacturing recipe of the 2500-year old sourdough bread from Subeixi cemetery in China. J. Proteomics 2014, 105, 363-371.

(156) Nelson, CJ.; Alexova, R.; Jacoby, RP.; Millar, AH. Proteins with high turnover rate in barley leaves estimated by proteome analysis combined with in planta isotope labeling. Plant Physiol. 2014, 166, 91-108.

(157) Schulte, D.; Close, TJ.; Graner, A.; Langridge, P.; et al. The international barley sequencing consortium--at the threshold of efficient access to the barley genome. Plant Physiol. 2009, 149, 142-147.

(158) Mayer, K. F.; Waugh, R.; Brown, J. W.; Schulman, A.; et al. A physical, genetic and functional sequence assembly of the barley genome. Nature 2012, 491, $711-716$

(159) Brenchley, R.; Spannagl, M.; Pfeifer, M.; Barker, GL.; et al. Analysis of the bread wheat genome using whole-genome shotgun sequencing. Nature 2012, 491, 705-710.

(160) Komatsu, S.; Hiraga, S.; Yanagawa, Y. Proteomics techniques for the development of flood tolerant crops. J. Proteome Res. 2012b, 11, 68-78. 
(161) Khatoon, A.; Komatsu, S.; Rehman, S. Proteomics Analysis of Flooding-stressed Plant. Curr. Proteomics 2012a, 9, $217-231$.

(162) Mohamaddi, PP.; Nouri, MZ.; Komatsu, S. Proteome Analysis of Drought-Stressed Plants. Curr. Proteomics 2012a, 9, 232-244.

(163) Sobhanian, H.; Razavizadeh, R.; Nanjo, Y.; Ehsanpour, AA.; Jazii, FRM.; Komatsu, S. Proteome analysis of soybean leaves, hypocotyls and roots under salt stress. Proteome Sci. 2010, 19, 1-15.

(164) Hossain, Z.; Komatsu, S. Contribution of proteomic studies towards understanding plant heavy metal stress response. Front. Plant Sci. 2013, 3, 310.

(165) Swigonska, S.; Weidner, S. Proteomic analysis of response to long-term continuous stress in roots of germinating soybean seeds. J. Plant Physiol. 2013, 170, 470-479.

(166) Khatoon, A.; Rehman, S.; Hiraga, S.; Makino, T.; Komatsu, S. Organ-specific proteomics analysis for response mechanism in soybean seedlings under flooding stress. J. Proteomics 2012b, 75, 5706-5723.

(167) Hossain, Z.; Hajika, M.; Komatsu, S. Comparative proteome analysis of high and low cadmium accumulating soybeans under cadmium stress. Amino Acids 2012a, 43, 2393-2416.

(168) Mohammadi, PP.; Moieni, A.; Hiraga, S.; Komatsu, S. Organ-specific proteomic analysis of drought-stressed soybean seedlings. J. Proteomics 2012b, 75, 1906-1923.

(169) Alam, I.; Lee, DG.; Kim, KH.; Park, CH.; Sharmin, SA.; Lee, H.; Oh, KW.; Yun, BW.; Lee, BH. Proteome analysis of soybean roots under waterlogging stress at an early vegetative stage. J. Biosci. 2010a, 35, 49-62. 
(170) Alam, I.; Sharmin, SA.; Kim, KH.; Yang, JK.; Choi, MS.; Lee, BH. Proteome analysis of soybean roots subjected to short-term drought stress. Plant Soil 2010b, $333,491-505$.

(171) Hajduch, M.; Ganapathy, A.; Stein, JW.; Thelen, JJ. A systematic proteomic study of seed filling in soybean. Establishment of high-resolution two-dimensional reference maps, expression profiles, and an interactive proteome database. Plant Physiol. 2005, 137, 1397-1419

(172) Hossain, Z.; Komatsu, S. Potentiality of soybean proteomics in untying the mechanism of flood and drought stress tolerance. Proteomes 2014, 2, 107-127.

(173) Agrawal, GK.; Thelen, JJ. Large scale identification and quantification profiling of phosphoproteins expressed during seed filling in oilseed rape. Mol. Cell. Proteomics 2006, 5, 2044-2059.

(174) Agrawal, GK.; Hajduch, M.; Graham, K.; et al. In-depth investigation of the soybean seed-filling proteome and comparison with aparallel study of rapeseed. Plant Physiol. 2008, 148, 504-518.

(175) Komatsu, S.; Yamamoto, R.; Nanjo, Y.; Mikami, Y.; Yunokawa, H.; Sakata, K. A comprehensive analysis of the soybean genes and proteins expressed under flooding stress using transcriptome and proteome techniques. J. Proteome Res. 2009a, 8, $4766-4778$.

(176) Hashiguchi, A.; Sakata, K.; Komatsu, S. Proteome analysis of early-stage soybean seedlings under flooding stress. J. Proteome Res. 2009, 8, 2058-2069

(177) Aghaei, K.; Ehsanpour, AA.; Shah, AH.; Komatsu, S. Proteome analysis of soybean hypocotyl and root under salt stress. Amino Acids 2009, 36, 91-98.

(178) Sobhanian, H.; Aghaei, K.; Komatsu, S. Changes in the plant proteome resulting from salt stress: toward the creation of salt-tolerant crops? J. Proteomics 2011, 74, 
$1323-1337$

(179) Ahsan, N.; Nanjo, Y.; Sawada, H.; Kohno, Y.; Komatsu, S. Ozone stress-induced proteomic changes in leaf total soluble and chloroplast proteins of soybean reveal that carbon allocation is involved in adaptation in the early developmental stage. Proteomics 2010, 10, 2605-2619.

(180) Hossain, Z.; Nouri, MZ.; Komatsu, S. Plant cell organelle proteomics in response to abiotic stress. J. Proteome Res. 2012b, 11, 37-48

(181) Komatsu, S.; Oh, MW.; Jang, HY.; Kwon, SJ.; Kim, HR.; Ko, JH.; Woo, SH.; Nanjo, Y. Proteomic analyses of soybean root tips during germination. Protein Pept. Lett. 2014b, 21, 1308-1319.

(182) FAOSTAT. Faostat.fao.org/site, 2012.

(183) FAOSTAT. Faostat.fao.org/site, 2009.

(184) Young, N.; Bharti, A. Genome-enabled insights into legume biology. Annu. Rev. Plant Biol. 2012, 63, 283-305.

(185) Jain, M.; Misra, G.; Patel, RK.; Priya, P.; Jhanwar, S.; Khan, AW.; et al. A draft genome sequence of the pulse crop chickpea (Cicer arietinum L.). Plant J. 2013, $74,715-729$.

(186) Varshney, RK.; Song, C.; Saxena, RK.; Azam, S.; Yu, S.; Sharpe, AG.; et al. Draft genome sequence of chickpea (Cicer arietinum) provides a resource for trait improvement. Nat. Biotechnol. 2013, 31, 240-246.

(187) Buhariwalla, HK.; Jayashree, B.; Eshwar, K.; Crouch, JH. Development of ESTs from chickpea roots and their use in diversity analysis of the Cicer genus. BMC Plant Biol. 2005, 5, 16-21. 
(188)Coram, TE.; Pang, CKE. Expression profiling of chickpea genes differentially regulated during a resistance response to Ascochyta rabiei. Plant Biotech. J. 2006, 4, 647-666.

(189) Mantri, NL.; Ford, R.; Coram, TE.; Pang, CKE. Transcriptional profiling of chickpea genes differentially regulated in response to high-salinity, cold and drought. BMC Genomics 2007, 8, 303-312.

(190) Ashraf, N.; Ghai, D.; Barman, P.; Basu, S.; Nagaraju, G.; Mandal, MK.; Chakraborty, N.; Datta, A.; Chakraborty, S. Comparative analyses of genotype dependent expressed sequence tags and stress-responsive transcriptome of chickpea wilt illustrates predicted and unexpected genes and novel regulators of plant immunity. BMC Genomics 2009, 10, 415

(191) Bhushan, D.; Pandey, A.; Chattopadhyay, A.; Choudhary, MK.; Chakraborty, S.; Datta, A.; Chakraborty, N. Extracellular matrix proteome of chickpea (Cicer arietinum) illustrates pathway abundance, novel protein functions and evolutionary perspect. J. Proteome Res. 2006, 5, 1711-1720.

(192) Pandey, A.; Chakraborty, S.; Datta, A.; Chakraborty, N. Proteomics approach to identify dehydration responsive nuclear proteins from chickpea (Cicer arietinum L.). Mol. Cell. Proteomics 2008, 7, 88-107.

(193) Pandey, A.; Choudhary, MK.; Bhushan, D.; Chattopadhyay, A.; Chakraborty, S.; Datta, A.; Chakraborty, N. The nuclear proteome of chickpea (Cicer arietinum L.) reveals predicted and unexpected proteins. J. Proteome Res. 2006, 5, 3301-3311.

(194) Bhushan, D.; Jaiswal, DK.; Ray, D.; Basu, D.; Datta, A.; Chakraborty, S.;

Chakraborty, N. Dehydration-responsive reversible and irreversible changes in the extracellular matrix: comparative proteomics of chickpea genotypes with contrasting tolerance. J. Proteome Res. 2011, 10, 2027-2046. 
(195) Bhushan, D.; Pandey, A.; Choudhary, MK.; Datta, A.; Chakraborty, S.;

Chakraborty, N. Comparative proteomics analysis of differentially expressed proteins in chickpea extracellular matrix during dehydration stress. Mol. Cell.

Proteomics 2007, 6, 1868-1884.

(196) Gupta, S.; Wardhan, V.; Verma, S.; Gayali, S.; Rajamani, U.; Datta, A.;

Chakraborty, S.; Chakraborty, N. Characterization of the secretome of chickpea suspension culture reveals pathway abundance and the expected and unexpected secreted proteins. J. Proteome Res. 2011, 10, 5006-5015.

(197) Subba, P.; Barua, P.; Kumar, R.; Datta, A.; Soni, K.; Chakraborty, S.; Chakraborty, N. Phosphoproteomic dynamics of chickpea (Cicer arietinum L.) reveals shared and distinct components of dehydration response. J. Proteome Res. 2013a, 12, 5025-5047.

(198) Kumar, R.; Kumar, A.; Subba, P.; Gayali, S.; Barua, P.; Chakraborty, S.; Chakraborty, N. Nuclear phosphoproteome of developing chickpea seedlings (Cicer arietinum L.) and protein-kinase interaction network. J. Proteomics 2014, $10,58-73$.

(199) Heidarvand, L.; Maali, AR. What happens in plant molecular responses to cold stress? Acta Physiol. Plant 2010, 32, 419-431.

(200) Chakraborty, S.; Pandey, A.; Datta, A.; Chakraborty, N.; Nucleus. In: Agrawal GK, Rakwal R (eds) Plant Proteomics : Technology, Strategies and Applications, John Wiley \& Sons, Inc., New Jersey, USA, 2008, pp 327-338.

(201) Narula, K.; Datta, A.; Chakraborty, N.; Chakraborty, S. Comparative analyses of nuclear proteome: extending its function. Front. Plant Sci. 2013, 4, 100.

(202) Narula, K.; Elagamy, E.; Datta, A.; Chakraborty, N.; Chakraborty, S. Comparative analyses of extracellular matrix proteome: an under-explored area in 
plant research. In: Goyal A (ed), Crop Plants. In Tech, Janeza Tradine, Croatia, 2012, pp145-166.

(203) Jaiswal, DK.; Ray, D.; Subba, P.; Mishra, P.; Gayali, S.; Datta, A.; Chakraborty, S.; Chakraborty, N. Proteomic analysis reveals the diversity and complexity of membrane proteins in chickpea (Cicer arietinum L.). Proteome Sci. 2012, 10, 59.

(204) Millan, THJ.; Clarke, KHM.; Siddique, HK.; Bhuriwalla, PM.; Gaur, J.; Kumar, J.; Gil, G. K.; Winter P. Chickpea molecular breeding: new tools and concepts. Euphytica 2006, 147, 81-103.

(205) Subba, P.; Kumar, R.; Gayali, S.; Shekhar, S.; Parveen, S.; Pandey, A.; Datta, A.; Chakraborty, S.; Chakraborty, N. Characterization of the nuclear proteome of a dehydration- sensitive cultivar of chickpea and comparative proteomic analysis with a tolerant cultivar. Proteomics 2013b, 13, 1973-1992.

(206) Jaiswal, DK.; Mishra, P.; Subba, P.; Rathi, D.; Chakraborty, S.; Chakraborty, N. Membrane-associated proteomics of chickpea identifies Sad1/UNC-84 protein (CaSUN1), a novel component of dehydration signaling. Scientific Rep. 2014, 4, 4177.

(207) Wardhan, V.; Jahan, K.; Gupta, S.; Chennareddy, S.; Datta, A.; Chakraborty, S.; Chakraborty, N. Overexpression of CaTLP1, a putative transcription factor in chickpea (Cicer arietinum L.), promotes stress tolerance. Plant Mol. Biol. 2012, $79,479-493$.

(208) Zuber, H.; Poignavent, G.; Le Signor, C.; Aimé, D.; Vieren, E.; Tadla, C.; Lugan, R.; Belghazi, M.; Labas, V.; Santoni, AL.; Wipf, D.; Buitink, J.; Avice, J.C.; Salon, C.; Gallardo K. Legume adaptation to sulfur deficiency revealed by comparing nutrient allocation and seed traits in Medicago truncatula. Plant J. 2013, 76, 982-996. 
(209) D'Hooghe, P.; Dubousset, L.; Gallardo, K.; Kopriva, S.; Avice, JC.; Trouverie, J. Evidence for proteomic and metabolic adaptations associated with alterations of seed yield and quality in sulfur-limited Brassica napus L. Mol. Cell. Proteomics 2014, 13, 1165-1183.

(210) Giridhar, P.; Obul Reddy, B.; Ravishankar, GA. Silver nitrate influences in vitro shoot multiplication and root formation in Vanilla planifolia Andr. Curr Sci. 2001, $81,1166-1170$.

(211) Chandran, S.; Puthur, JT. Assorted response of mutated variants of Vanilla planifolia Andr. towards drought. Acta Physiol. Plant 2009, 31, 1023-1029

(212) Walton, NJ.; Mayer, MJ.; Narbad, A. Molecules of interest-vanillin. Phytochemistry 2003, 63, 505-515.

(213) Bory, S.; Grisoni, M.; Duval, MF.; Besse, P. Biodiversity and preservation of vanilla: present state of knowledge. Genet Resour. Crop Evol. 2008, 55, 551-571

(214) Divakaran, M.; Jayakumar, VN.; Veena, SS.; Vimala, J.; Basha, A.; Saji, KV.; Nirmal, Babu, K.; Peter, KV. Genetic variations and interrelationships in Vanilla planifolia and few related species as expressed by RAPD polymorphism. Genet. Resour. Crop Evol. 2008, 55, 459-470

(215) Rao, SR.; Ravishankar, GA. Vanilla flavour: production by conventional and biotechnological routes. J. Sci. Food Agric. 2000, 80, 289-304.

(216) Tan, BC.; Chin, CF.; Alderson, P. Optimisation of plantlet regeneration from leaf and nodal derived callus of Vanilla planifolia Andrews. Plant Cell Tiss. Org. Cult. 2011, 105, 457-463

(217) Geetha, S.; Shetty, SA. In vitro propagation of Vanilla planifolia, a tropical orchid. Curr. Sci. 2000, 79, 886-889

(218) Gu, Z.; Arditti, J.; Nyman, LP. Vanilla planifolia: callus induction and plantlet 
production in vitro. Lindleyana $1987,2,48-52$

(219) Janarthanam, B.; Seshadri, S. Plantlet regeneration from leaf derived callus of Vanilla planifolia Andr. In Vitro Cell Dev. Biol.-Plant 2008, 44, 84-89.

(220) Kalimuthu, K.; Senthilkumar, R.; Murugalatha, N. Regeneration and mass multiplication of Vanilla planifolia Andr.-a tropical orchid. Curr. Sci. 2006, 91, $1401-1403$.

(221) Kononowicz, H.; Janick, J. In vitro propagation of Vanilla planifolia. Hort. Sci. 1984, $19,58-59$

(222) Lee-Espinosa, HE.; Murguı'a-Gonza'lez, J.; Garc1'a-Rosas, B.;

Co'rdova-Contreras, AL.; Laguna-Cerda, A.; Mijangos-Corte's, JO.;

Barahona-Pe'rez, LF.; Iglesias-Andreu, LG.; Santana-Buzzy, N. In vitro clonal propagation of vanilla (Vanilla planifolia 'Andrews'). Hort. Sci. 2008, 43, 454458.

(223) Tan, BC.; Chin, CF.; Liddell, S.; Alderson, P. Proteomic analysis of callus development in Vanilla planifolia Andrews, 2013, 31, 1220-1229

(224) Palama, TL.; Menard, P.; Fock, I.; Choi, YH.; Bourdon, E.; Govinden-Soulange, J.; Bahut, M.; Payet, B.; Verpoorte, R.; Kodja, H. Shoot differentiation from protocorm callus cultures of Vanilla planifolia (Orchidaceae) : proteomic and metabolic responses at early stage. BMC Plant Biol. 2010, 10, 82-100

(225) Gallage, NJ.; Hansen, EH.; Kannangara, R.; Olsen, CE.; Motawia, MS.; JØrgensen, K.; Holme, I.; Hebelstrup, K.; Grisoni, M.; MØller, BL. Vanillin formation from ferulic acid in Vanilla planifolia is catalysed by a single enzyme. Nature Comun. 2004, 5, 4037.

(226) Saker, M. M.; Moursy, H. A. Molecular characterisation of Egyptian date palm cultivars: RAPD fingerprints. Arab. J. Biotechnol 1999, 2, 71-78. 
(227) Sallon, S.; Solowey, E.; Cohen, Y.; Korchinsky, R.; Egli, M.; Woodhatch, I.;

Simchoni, O.; Kislev, M. Germination, genetics, and growth of an ancient date seed. Science 2008, 320, 1464.

(228) Morton, J. Date in fruits of warm climates, Morton, J., Ed. Purdue University center for new crops and plants 1987, pp 5-11.

(229) Vayalil, PK. Date fruits (Phoenix dactylifera Linn): an emerging medicinal food. Crit. Rev. Food Sci. Nutr. 2012, 52, 249-71.

(230) Maier, V. P.; Metzler, D. M. Quantitative changes in date polyphenols and their relation to browning. J. Food Sci. 1965, 30, 80-84.

(231) Kikuchi, N.; Miki, T. Separation of date (Phoenix dactylifera) sterols by liquid-chromatography. Mikrochim Acta 1978, 1, 89-96.

(232) FAOSTAT. Faostat.fao.org/site, 2014.

(233) El-Rayes, D. A. Characterization of three date palm cultivars based on RAPD finger prints and fruit chemical composition. Environ. Arid. Agric. Sci. 2009, 20, $3-20$.

(234) Yang, M.; Zhang, X.; Liu, G.; Yin, Y.; Chen, K.; Yun, Q.; Zhao, D.; Al-Mssallem, IS.; Yu, J. The complete chloroplast genome sequence of date palm (Phoenix dactylifera L.). PLoS One 2010, 5, e12762.

(235) Meekijjaroenroj, A.; Anstett, M. C. A weevil pollinating the Canary Islands date palm: between parasitism and mutualism. Naturwissenschaften 2003, 90, 452-455. (236) Asensio, L.; Lopez-Jimenez, JA.; Lopez-Llorca, LV. Mycobiota of the date palm phylloplane: description and interactions. Rev. Iberoam. Micol. 2007, 24, 299-304. (237) Dihazi, A.; Jaiti, F.; Taktak, W; Kilani-Feki, O.; Jaoua, S.; Driouich, A.; Baaziz, M.; Daayf, F.; Serghini, M. A., Use of two bacteria for biological control of bayoud disease caused by Fusarium oxysporum in date palm (Phoenix dactylifera $\mathrm{L}$ ) 
seedlings. Plant Physiol. Biochem. 2012, 55, 7-15.

(238) Al-Dous, EK.; George, B.; Al-Mahmoud, ME.; Al-Jaber, MY.; Wang, H.;

Salameh, YM.; Al-Azwani, EK.; Chaluvadi, S.; Pontaroli, AC.; DeBarry, J.;

Arondel, V.; Ohlrogge, J.; Saie, IJ.; Suliman-Elmeer, KM.; Bennetzen, JL.;

Kruegger, RR.; Malek, JA. De novo genome sequencing and comparative

genomics of date palm (Phoenix dactylifera). Nat. Biotechnol. 2011, 29, 521-527.

(239) Marques, J.; Duran-Vila, N.; Daros, J. A. The Mn-binding proteins of the photosystem II oxygen-evolving complex are decreased in date palms affected by brittle leaf disease. Plant Physiol. Biochem. 2011, 49, 388-94.

(240) Sghaier-Hammami, B.; Drira, N.; Jorrin-Novo, JV.; Comparative 2-DE proteomic analysis of date palm (Phoenix dactylifera $\mathrm{L}$.) somatic and zygotic embryos. J. Proteomics 2009, 73, 161-77.

(241) Marondedze, C.; Gehring, C.; Thomas, L. Dynamic changes in the date palm fruit proteome during development and ripening. Hort. Res. 2014, 1, 14039.

(242) Marondedze, C.; Turek, I.; Parrott, B.; Thomas, L.; Jankovic, B.; Lilley, KS.;

Gehring C. Structural and functional characteristics of cGMP-dependent methionine oxidation in Arabidopsis thaliana proteins. Cell Commun. Signal 2013, 11,1 .

(243) Rugman-Jones, PF.; Hoddle, CD.; Hoddle, MS, Stouthamer, R. The lesser of two weevils: molecular-genetics of pest palm weevil populations confirm Rhynchophorus vulneratus (Panzer 1798) as a valid species distinct from R. ferrugineus (Olivier 1790), and reveal the global extent of both. PLoS One 2013, 8, e78379.

(244) Al-Farsi, M.; Alasalvar, C.; Morris, A.; Baron, M.; Shahidi, F. Compositional and sensory characteristics of three native sun-dried date (Phoenix dactylifera L.) 
varieties grown in Oman. J. Agric. Food Chem. 2005, 53, 7586-7591.

(245) Cellini, F.; Chesson, A.; Colquhoun, I.; Constable, A.; Davies, H.V.; Engel, K.H.;

Gatehouse, A.M.; Kärenlampi, S.; Kok, E.J.; Leguay, J.J.; Lehesranta, S.;

Noteborn, H.P.; Pedersen, J.; Smith, M. Unintended effects and their detection in genetically modified crops. Food. Chem. Toxicol. 2004, 42, 1089-125.

(246) Zolla, L.; Rinalducci, S.; Antonioli, P.; Righetti, P.G. Proteomics as a complementary tool for identifying unintended side effects occurring in transgenic maize seeds as a result of genetic modifications. J. Proteome Res. 2008, 7, $1850-1861$.

(247) Barros, E.; Lezar, S.; Anttonen, M.J.; van Dijk, J.P.; Röhlig, R.M.; Kok, E.J.; Engel, K.H. Comparison of two GM maize varieties with a near-isogenic non-GM variety using transcriptomics, proteomics and metabolomics. Plant Biotechnol. J. 2010, 8, 436-451.

(248) Ruebelt, M.C.; Lipp, M.; Reynolds, T.L.; Schmuke, J.J.; Astwood, J.D.; DellaPenna, D.; Engel, K.H.; Jany, K.D. Application of two-dimensional gel electrophoresis to interrogate alterations in the proteome of genetically modified crops. 3. Assessing unintended effects. J. Agric. Food Chem. 2006a, 54, 2169-2177.

(249) Ruebelt, M.C.; Lipp, M.; Reynolds, T.L.; Astwood, J.D.; Engel, K.H.; Jany, K.D. Application of two-dimensional gel electrophoresis to interrogate alterations in the proteome of genetically modified crops. 2. Assessing natural variability. J. Agric. Food Chem. 2006b, 54, 2162-2168.

(250) Burstin, J.; de Vienne, D.; Dubreuil, P.; Damerval, C. Molecular markers and protein quantities as genetic descriptors in maize .1. Genetic diversity among 21 inbred lines. Theor. Appl. Genet. 1994, 89, 943-950. 
(251) Thiellement, H; Bahrman, N.; Damerval, C; Plomion, C.; Rossignol, M; Santoni, V.; de Vienne, D; Zivy, M. Proteomics for genetic and physiological studies in plants. Electrophoresis 1999, 20, 2013-2026.

(252) Bourgeois, M.; Jacquin, F.; Cassecuelle, F.; Savois, V.; Belghazi, M.; Aubert, G.; Quillien, L.; Huart, M.; Marget, P.; Burstin, J. A PQL (protein quantity loci) analysis of mature pea seed proteins identifies loci determining seed protein composition. Proteomics 2011, 11, 1581-1594.

(253) Zivy, M.; de Vienne, D. Proteomics: a link between genomics, genetics and physiology. Plant. Mol. Biol. 2000, 44, 575-580.

(254) Ghabooli, M.; Khatabi, B.; Ahmadi, FS.; Sepehri, M.; et al. Proteomics study reveals the molecular mechanisms underlying water stress tolerance induced by Piriformospora indica in barley. J. Proteomics 2013, 94, 289-301.

(255) Jin, Z.; Li, XM.; Gao, F.; Sun, JY.; et al. Proteomic analysis of differences in barley (Hordeum vulgare) malts with distinct filterability by DIGE. J. Proteomics 2013b, 93, 93-106.

(256) Kaspar, S.; Matros, A.; Mock, HP. Proteome and flavonoid analysis reveals distinct responses of epidermal tissue and whole leaves upon UV-B radiation of barley (Hordeum vulgare L.) seedlings. J. Proteome Res. 2010, 9, 2402-2411.

(257) Witzel, K.; Weidner, A.; Surabhi, GK.; Borner, A.; Mock, HP. Salt stress-induced alterations in the root proteome of barley genotypes with contrasting response towards salinity. J. Exp. Bot. 2009, 60, 3545-3557.

(258) Witzel, K.; Weidner, A.; Surabhi, GK.; Varshney, RK.; et al. Comparative analysis of the grain proteome fraction in barley genotypes with contrasting salinity tolerance during germination. Plant Cell Environ. 2010, 33, 211-222. 
(259) Komatsu, S.; Sugimoto, T.; Hoshino, T.; Nanjo, Y.; Furukawa, K. Identification of flooding stress responsible cascades in root and hypocotyl of soybean using proteome analysis. Amino Acids 2010b, 38, 729-738.

(260) Khatoon, A.; Rehman, S.; Oh, MW.; Woo, SH.; Komatsu, S. Analysis of response mechanism in soybean under low oxygen and flooding stresses using gel-base proteomics technique. Mol. Biol. Rep. 2012c, 39, 10581-10594.

(261) Alam, I.; Sharmin, SA.; Kim, KH.; Kim, YG.; Lee, JJ.; Bahk, JD.; Lee, BH. Comparative proteomic approach to identify proteins involved in flooding combined with salinity stress in soybean. Plant Soil 2011, 346, 45-62.

(262) Nouri, MZ.; Komatsu, S. Comparative analysis of soybean plasma membrane proteins under osmotic stress using gel-based and LC MS/MS-based proteomics approaches. Proteomics 2010, 10, 1930-1945.

(263) Toorchi, M.; Yukawa, K.; Nouri, MZ.; Komatsu S. Proteomics approach for identifying osmotic-stress-related proteins in soybean roots. Peptides 2009, 30, $2108-2117$.

(264) Galant, A.; Koester, RP.; Ainsworth, EA, Hicks, LM, Jez, JM. From climate change to molecular response: redox proteomics of ozone-induced responses in soybean. New Phytol. 2012, 194, 220-229.

(265) Xu, C.; Sullivan, JH.; Garrett, WM.; Caperna, TJ.; Natarajan, S. Impact of solar ultraviolet-B on the proteome in soybean lines differing in flavonoid contents. Phytochemistry 2008b, 69, 38-48.

(266) Xu, XY.; Fan, R.; Zheng, R.; Li, CM.; Yu, DY. Proteomic analysis of seed germination under salt stress in soybeans. J. Zhejiang Univ. Sci. B 2011, 12, 507-517. 
(267) Vessal, S.; Siddique, KH.;Atkins, CA. Comparative proteomic analysis of genotypic variation in germination and early seedling growth of chickpea under suboptimal soil-water conditions. J. Proteome Res. 2012, 11, 4289-4307. 
Figure legend

Figure 1. Comparison of number of proteomic studies amongst different crop plants based on PubMed search (www.pubmed.gov) (as of September 23, 2014). 
3 Table 1. A summary of Published Papers on Crop Proteomics since 2008.

\begin{tabular}{|c|c|c|c|c|c|c|}
\hline $\begin{array}{ll}4 & \text { Crop } \\
5 & \end{array}$ & Genotypes & $\begin{array}{l}\text { Growth stage/ } \\
\text { organ/ subcellular }\end{array}$ & Treatment/ stress & Proteomics technique & Topic & References \\
\hline 6 Rice & Indica (93-11) & Embryo & development & Gel-based & embryogenesis & 41,42 \\
\hline 7 & MxA & Young florets & & Gel-free & Male sterility & 38 \\
\hline 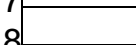 & Yuetai A & Anther & & Gel-free & Male sterility & 37 \\
\hline 8 & GZ63S & Pistil & & Gel-free & Pollination & 39 \\
\hline & Taichung Native 1 & Leaf sheath & Brown Planthopper & Gel-free & Pesticide resistance & 56,57 \\
\hline $\begin{array}{ll}1 \\
1 \mid 1 \\
1\end{array}$ & $\begin{array}{l}\text { Japonica } \\
\text { (Wuyuiing3) }\end{array}$ & Seed & & Gel-free & Grain filling & 15 \\
\hline $\begin{array}{l}1 / 2 \\
1 / 3\end{array}$ & $\begin{array}{l}\text { Japonica } \\
\text { (Nipponbare) }\end{array}$ & Seed & imbibition & Gel-based & Seed germination & $25,27,28$ \\
\hline $\begin{array}{l}14 \\
15\end{array}$ & $\begin{array}{l}\text { Japonica } \\
\text { (Nipponbare) }\end{array}$ & Embryo & imbibition & Gel-free & Seed germination & $24-26$ \\
\hline 16 & $\begin{array}{l}\text { Japonica } \\
\text { (Nipponbare) }\end{array}$ & Seedling, leaf & $\begin{array}{l}12 \mathrm{~h} \mathrm{light} / 12 \mathrm{~h} \text { dark } \\
\text { cycle }\end{array}$ & Gel-based & circadian rhythms & 30,31 \\
\hline 18 & $\begin{array}{l}\text { Japonica } \\
\text { (Nipponbare) }\end{array}$ & Roots, leaves & Cadmium, arsenate & Gel-based & Heavy metal stress & 45,46 \\
\hline 20 & $\begin{array}{l}\text { Japonica } \\
\text { (Nipponbare) }\end{array}$ & leaf & Fungi inoculation & $\begin{array}{l}\text { Gel-based, } \\
\text { Gel-free }\end{array}$ & Disease resistance & $52-55$ \\
\hline $\begin{array}{l}21 \\
22\end{array}$ & $\begin{array}{l}\text { Japonica } \\
\text { (Nipponbare) }\end{array}$ & Embryo, endosperm & development & Gel-based & Grain filling & 40,43 \\
\hline $\begin{array}{l}23 \\
24\end{array}$ & $\begin{array}{l}\text { Japonica } \\
\text { (Nipponbare) }\end{array}$ & Egg, sperm cells & & Gel-based & Gametephyte development & 34 \\
\hline 25 & IR64, Cheriviruppu & Anther & Salt & Gel-based & Pollen development & 36 \\
\hline 26 Maize & MO16,B73 & Leaf, bundle sheath & & Gel-free (LC-MS/MS) & C4 Leaf Development and Differentiation & 81 \\
\hline 27 & \begin{tabular}{|l|} 
WT-T43 \\
\end{tabular} & seedling/ chloroplast & & Gel-free (LC-MS/MS) & leaf M and BS chloroplasts & 82 \\
\hline 28 & $\begin{array}{l}\text { W22-T43, } \\
\text { B73 }\end{array}$ & $\begin{array}{l}\text { leaf base, } \\
\text { tip/chloroplast }\end{array}$ & & Gel-free (LC-MS/MS) & Nucleoid Functions & 83 \\
\hline 29 & B73 & root hairs & & Gel-free (LC-MS/MS) & reference proteome & 62 \\
\hline 30 & W22 (ga1 and Gal2) & Pollen, pistil & & Gel-free (LC-MS/MS) & mechanism of gametophytic factors & 63 \\
\hline 33 & $\begin{array}{l}\text { Inbred lines } \\
\text { Mo17/B73, their } \\
\text { hybrid Mo17/B73 }\end{array}$ & $\begin{array}{l}\text { Basal region of } \\
\text { seedling leaf/nuclear }\end{array}$ & & 2-DE & $\begin{array}{l}\text { Nuclear proteome and differentially expressed } \\
\text { proteins between a hybrid and its parental lines }\end{array}$ & 65 \\
\hline $\begin{array}{l}34 \\
35\end{array}$ & $\begin{array}{l}\text { Nongda 108, } \\
\text { Zhengdan } 958\end{array}$ & Endosperm, embryo & & 2-DE & Grain filling rate & 66 \\
\hline 36 & Zong3/87-1, & Embryos & & 2-DE & heterosis in radicle emergence & 68 \\
\hline 37 & FR697 & 15-d-old plants & drought & 2-DE & xylem sap & 135 \\
\hline 38 & Nongda 108 & Embryos & dessication & 2-DE & development and germination of embryos & 75 \\
\hline 39 & A19 & Anther & Cold pretreatment & 2-DE & Induction of microspore embryogenesis & 69 \\
\hline
\end{tabular}

69 
B73

SR12

SR12

BeiDan 1

Siyi, Mo17

Nongda 108

pb269, pb369

B73

B73

B73

Wild 5660

Mutant line 5660M

Shanrong 3, Jinan

177

landraces (N49,

N14)

Shiroganekomugi

Jimai 20, Zhoumai 16

Trangenic,

Wild-Yumai 18

Zhengmai 9023

Duilio

Tolerent (Roshan)

Sensitive (Ghods)

Calingiri,

Wyalk-atchem, Janz

Jing-411, Chinese

Spring

Durum

Ofanto

Kukri (intolerant),

Excalibur (tolerant),

RAC875 (tolerant)

Pollen coat

Pollen coat

Seedling/chloroplast

Root

Seedling

Embryos

Seedling

Leaf

Seed flour

Leaf

Leaf

Seed

Spike Development

Leaf

Peduncle

Root

Developing grain

Seed

Leaf

Leaf

Seed

Mitochondria

Root

Seed

Seed

Leaf

Leaf

\begin{tabular}{|c|}
\hline Salt \\
\hline Salt \\
\hline Nitric Oxide/ Salt \\
\hline Salt \\
\hline $\begin{array}{l}\text { Sugarcane mosaic } \\
\text { virus }\end{array}$ \\
\hline
\end{tabular}

2-DE

2-DE

2-DE

2-DE

2-DE

Flooding

2D-DIGE

Pollen coat proteome

Salt impact on the plastidic protein pattern

Early post-translational phosphorylation

Germinating seed

\begin{tabular}{l|l} 
Plant pathogen interaction & 73 \\
\hline
\end{tabular}

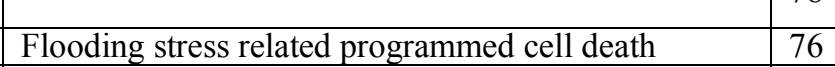

discrimination of the inbred lines using seed flour

proteome

\begin{tabular}{|c|c|c|c|}
\hline & $2-\mathrm{DE}$ & & \\
\hline salicylic acid, & 2-DE & The effects of phytohormones & 80 \\
\hline
\end{tabular}

\begin{tabular}{l|l} 
abscisic acid & 2-DE \\
\hline
\end{tabular}

Proteomic and Phosphoproteomic analysis

Gel-free $\quad$ Establishing protein networks during seed

development

Identification of autonomous pathway protein for

spike development

\begin{tabular}{|l|l|l|l} 
Cold & 2-DE & $\begin{array}{l}\text { Identicicaton } \\
\text { spike development }\end{array}$ & 119 \\
\hline
\end{tabular}

\begin{tabular}{|l|l|l|l}
\hline Drought, salinity & $2-\mathrm{DE} / \mathrm{MS}$ & Drought and salinity responsive proteins & 88
\end{tabular}

\begin{tabular}{|l|l|l|l|l}
\hline Drought, oxidative & 2-DE & Efficient remobilization of pre-stored carbohydrates & 95
\end{tabular}

Flooding $\quad$ Gel base/LC-MS/MS

\begin{tabular}{l|l} 
Efficient remobilization of pre-stored carbohydrates & 95 \\
\hline
\end{tabular}

2-DE/MALDI-

TOF/TOF-MS

\begin{tabular}{l|l} 
Grain development & 136 \\
\hline
\end{tabular}

2-DE

\begin{tabular}{|l|l} 
& $2-\mathrm{DE}$ \\
\hline Salt & 2D-DIGE \\
\hline Salt & Gel free \\
\hline Salt & $2-\mathrm{DE}$ \\
\hline Salt & 2DE/ LC- MS/MS
\end{tabular}

Role of trx $\mathrm{h}$ gene for seed germination

$\begin{array}{ll}\text { Biochemical bases for salt tolerance in wheat } & 103\end{array}$

Understanding the biochemical response to salinity 100

sensitive and tolerance cultivars

113

\begin{tabular}{|l|l} 
Mitochondrial ROS defense pathways & 91
\end{tabular}

\begin{tabular}{|l|l|l|l} 
Salt & $2-\mathrm{DE}$ & Cultivar specific root responses & 101
\end{tabular}

\begin{tabular}{|c|c|c|c|}
\hline Salt & Gel- free & $\begin{array}{l}\text { Potential biomarkers of priming-induced salt } \\
\text { tolerance }\end{array}$ & 114 \\
\hline Salt & $\begin{array}{l}\text { 2-DE/ MALDI- TOF } \\
\text { MS }\end{array}$ & Identification of changes in protein profile & 112 \\
\hline Drought & iTRAQ & $\begin{array}{l}\text { Potential candidates for genetic manipulation to } \\
\text { enhance drought tolerance }\end{array}$ & 107 \\
\hline
\end{tabular}

70

ACS Paragon Plus Environment 


\begin{tabular}{|c|c|c|c|c|c|}
\hline $\begin{array}{l}\text { Gaocheng } 8901 \text {, } \\
\text { Jagger, Nongda } \\
3406\end{array}$ & Grain & Drought & 2- DE & $\begin{array}{l}\text { Elucidate the adverse effects of drought on wheat } \\
\text { grain quality }\end{array}$ & 108 \\
\hline $\begin{array}{l}\text { TR39477, TTD22, } \\
\text { Kiz1ltan }\end{array}$ & Leaf & Drought & $\begin{array}{l}\text { 2- DE/ LC-ESI- } \\
\text { MS/MS }\end{array}$ & $\begin{array}{l}\text { Investigation of PTMs of transcripts, proteome } \\
\text { profiling and candidate genes for molecular breeding } \\
\text { studies }\end{array}$ & 111 \\
\hline Kauz, Janz & Grain & Drought & $\begin{array}{l}\text { 2-DE/ MALDI-TOF } \\
\text { MS }\end{array}$ & Drought-responsive mechanisms, grain development & 109 \\
\hline $\begin{array}{l}\text { Pale-green mutant } \\
\text { (MD-597), } \\
\text { wild-type (Borgia) }\end{array}$ & Anthesis period & Drought & $\begin{array}{l}\text { 2- DE/ } \\
\text { MALDI-TOF-MS }\end{array}$ & $\begin{array}{l}\text { Alterations in photosystems, effect of pigment } \\
\text { content in the molecular response to drought }\end{array}$ & 89 \\
\hline Yumai 34 & Seed & Drought & 2- DE & $\begin{array}{l}\text { Molecular mechanisms underlying SA-induced } \\
\text { drought tolerance }\end{array}$ & 105 \\
\hline Svevo & Seed & High temperature & 2- DE & $\begin{array}{l}\text { Consequences of heat stress on the accumulation of } \\
\text { nonprolamin proteins, elucidate wheat kernel } \\
\text { metabolic proteins }\end{array}$ & 92 \\
\hline Vinjett & Grain & High temperature & 2-DE/MS & $\begin{array}{l}\text { Stress-induced changes on the albumin and gliadin } \\
\text { proteomes }\end{array}$ & 98 \\
\hline Ofanto & Leaf & Drought & $\begin{array}{l}\text { 2-DE/ MALDI-TOF } \\
\text { MS }\end{array}$ & $\begin{array}{l}\text { Development of drought resistant wheat varieties, } \\
\text { stress induced proteome changes }\end{array}$ & 106 \\
\hline $\begin{array}{l}\text { Ningchun } 4, \\
\text { Chinese Spring }\end{array}$ & Grain & Drought & 2-DE/MALDI-TOF & $\begin{array}{l}\text { Understanding the biochemical mechanisms of } \\
\text { drought resistance, grain development }\end{array}$ & 110 \\
\hline Svevo & Flour & & $\begin{array}{l}\text { MALDI-TOF MS/ } \\
\text { LC-MS/MS }\end{array}$ & Characterization of glutenin subunits & 123 \\
\hline $\begin{array}{l}\text { Ofanto, Latino, } \\
\text { Simeto }\end{array}$ & Gluten Proteins & & 2- DE & Gluten proteome, grain quality performance & 128 \\
\hline $\begin{array}{l}\text { Jimai 20, Jin } 411, \\
\text { Zhoumai } 16\end{array}$ & Grain & & SDS-PAGE, HPLC & $\begin{array}{l}\text { Synthesis and accumulation of glutenin subunits, } \\
\text { grain development }\end{array}$ & 127 \\
\hline Opata, Nesser & Root & Abscisic acid & CB-X protein assay & Root protein changes in response to abscisic acid & 74 \\
\hline BG220 & Leaf & & 2D LC-MS (iTRAQ) & Effective approaches for shotgun proteomics & 16 \\
\hline Yumai 34 & Leafs and roots & Copper & $2-\mathrm{DE}$ & $\begin{array}{l}\text { Cu responsive proteins, molecular mechanism of } \\
\text { stress induced higher plants }\end{array}$ & 134 \\
\hline Keumkang & Root & Aluminum & $2-\mathrm{DE}$ & Stress and defense responsive proteins & 133 \\
\hline Yangmai 15 & Seed & Cadmium & 2-DE & $\begin{array}{l}\text { Heavy metal toxicity, molecular basis of } \mathrm{Cd} \\
\text { responses in plants }\end{array}$ & 132 \\
\hline JinMai 79 & Seed & $\begin{array}{l}\text { Enhanced UV-B } \\
\text { Radiation }\end{array}$ & 2- DE & Leaf responses under ultraviolet-B radiation & 131 \\
\hline Jinpum, Keumgang & Seed endosperms & & MALDI-TOF Mass & Cultivar-specific proteins & 122 \\
\hline Butte 86 & Flour & & $\begin{array}{l}\text { 2- DE, Size exclusion } \\
\text { chromatography/ } \\
\text { Tandem MS }\end{array}$ & $\begin{array}{l}\text { Accumulation of gliadins, characterization of wheat } \\
\text { flour quality }\end{array}$ & 130 \\
\hline
\end{tabular}




\begin{tabular}{|c|c|c|c|c|c|}
\hline Samanta, Sandra & Crown & Low temperature & 2-D DIGE & $\begin{array}{l}\text { Characterize individual hormonal responses, cold } \\
\text { acclimation }\end{array}$ & 118 \\
\hline Kohdasht & Leaf & Low temperature & 2- DE & $\begin{array}{l}\text { Long-term plant responses to cold exposure, identify } \\
\text { Krebs cycle enzymes, calvin cycle enzyme }\end{array}$ & 116 \\
\hline Jing 411, Sunstate & $\begin{array}{l}\text { Grain (post-anthesis } \\
\text { period) }\end{array}$ & & 2-D DIGE & $\begin{array}{l}\text { Accumulations of albumin and globulin, expression } \\
\text { profiling, grain quality }\end{array}$ & 124 \\
\hline Recital & Grain & & 2-DE, SDS-PAGE & Grain development, elucidate the metabolic pathway & 125 \\
\hline Recital & Grain & & 2- DE & Grain peripheral layers proteins, grain development & 126 \\
\hline $\begin{array}{l}\text { Katya, Sadovo, } \\
\text { Zlatitza, Miziya }\end{array}$ & Leaf & Drought & 2-DE, SDS-PAGE & $\begin{array}{l}\text { Changes in Rubisco level under stress } \\
\text { conditions }\end{array}$ & 96 \\
\hline $\begin{array}{l}\text { Tunis, Tunisia, Om } \\
\text { Rabia3 Mahmoudi }\end{array}$ & Mature embryos & Late embryogenesis & $\begin{array}{l}\text { 2- DE/ ProteomeLab } \\
\text { PF-2D }\end{array}$ & $\begin{array}{l}\text { Biochemical screen of adaptation to drought and salt } \\
\text { stress, embryo proteins }\end{array}$ & 129 \\
\hline Yumai 34 & Leaf & Low temperature & $2-\mathrm{DE}$ & $\begin{array}{l}\text { Freeze-stress responsive and accumulation of signal } \\
\text { transduction proteins }\end{array}$ & 117 \\
\hline Yumai 34 & Leaf & & 2- DE & $\begin{array}{l}\text { TaBTF3 gene virus-induced } \\
\text { Silenced, regulatory mechanism }\end{array}$ & 137 \\
\hline Norstar, Azar2 & Seed & Low temperature & 2- DE & $\begin{array}{l}\text { Cold acclimation and vernalization fulfillment } \\
\text { linkage at the molecular level }\end{array}$ & 115 \\
\hline $\begin{array}{l}\text { Mironovskaya } 808 \\
\text { (MIR), Bezostaya } 01 \\
\text { (BEZ) }\end{array}$ & Crown & Low temperature & 2- DE & Long-term cold acclimation, stress induced proteins & 99 \\
\hline Golden Promise & $\begin{array}{l}\text { Roots and shoots/ } 33 \\
\text { day seedlings }\end{array}$ & Nitrogen deficiency & 2-DE & $\begin{array}{l}\text { Long term nitrogen deficiency, short term nitrogen } \\
\text { starvation }\end{array}$ & 145 \\
\hline 8 Egyptian landraces & $\begin{array}{l}4 \text { extended leaf } \\
\text { seedlings, leaf }\end{array}$ & drought & 2D-DIGE & Drought stress in Egyptian barley varieties & 148 \\
\hline Pallas & $\begin{array}{l}\text { Leaf sheath/ } 14 \text { day } \\
\text { seedlings }\end{array}$ & $\begin{array}{l}\text { Salt/ fungal } \\
\text { infection }\end{array}$ & 2-DE & Salt tolerance with mutual fungal infection & 152 \\
\hline $\begin{array}{l}\text { Barke, Sloop, } \\
\text { Esterel, Morex, } \\
\text { Himalaya, Golden } \\
\text { Promise }\end{array}$ & Seed (review) & $\begin{array}{l}\text { grain filling/ } \\
\text { maturation }\end{array}$ & $2-\mathrm{DE}$ & $\begin{array}{l}\text { Protein composition changes during grain filling and } \\
\text { maturation }\end{array}$ & 142 \\
\hline Morex & $3 \mathrm{~cm}$ seedling roots & Nuclei isolation & $\begin{array}{l}\text { Flow cytometry, } \\
\text { SDS-PAGE }\end{array}$ & Cell sorting for purification of nuclei & 154 \\
\hline Baudin & $\begin{array}{l}\text { Leaf/ } 24 \text { day } \\
\text { hydroponic } \\
\text { seedlings }\end{array}$ & Protein turnover & $\begin{array}{l}\text { 15-N labelling, } \\
\text { SDS-PAGE }\end{array}$ & $\begin{array}{l}\text { Measuring protein turnover rate using in planta } \\
\text { isotope labelling }\end{array}$ & 156 \\
\hline $\begin{array}{l}\text { Bowman, } \\
\text { Bowman-rph15 }\end{array}$ & $\begin{array}{l}\text { Leaf/ first leaf stage } \\
\text { seedlings }\end{array}$ & Leaf rust infection & 2-DE & Defence responses to leaf rust & 150 \\
\hline Golden Promise & leaf & $\begin{array}{l}\text { Drought/ fungal } \\
\text { infection }\end{array}$ & 2-DE & Drought tolerance with mutual fungal infection & 254 \\
\hline Dan'er, Metcalfe & malts & Malt filterability & 2D DIGE & Malting quality discrimination & 255 \\
\hline
\end{tabular}




\begin{tabular}{|c|c|c|c|}
\hline UV-B radiation & $\begin{array}{l}\text { LC-MS/MS label free } \\
\text { quantitation }\end{array}$ & $\begin{array}{l}\text { UV-B radiation stress on whole leaf and epidermal } \\
\text { tissue }\end{array}$ & 256 \\
\hline Drought & 2-DE & Drought stress and drought tolerance & 149 \\
\hline Salinity & 2-DE & $\begin{array}{l}\text { Salt tolerance and salt sensitivity in different } \\
\text { genotypes }\end{array}$ & 151 \\
\hline Cadmium & 2-DE & $\begin{array}{l}\text { Ultrastructure and protein analysis of two barley } \\
\text { genotypes with contrasting cadmium accumulation } \\
\text { phenotypes }\end{array}$ & 147 \\
\hline Salt & 2-DE & Salt stress tolerance in different genotypes & 257 \\
\hline Salt & 2-DE & $\begin{array}{l}\text { Salinity tolerance during germination in different } \\
\text { genotypes }\end{array}$ & 258 \\
\hline Flooding & $\begin{array}{l}\text { 2-DE (IEF), } \\
\text { LC-MS/MS }\end{array}$ & $\begin{array}{l}\text { Energy (glycolysis, pyruvate decarboxylation, TCA } \\
\text { cycle), amino acid synthesis, flavonoid biosynthesis }\end{array}$ & 166 \\
\hline Flooding & $\begin{array}{l}\text { 2-DE (IEF/IPG), } \\
\text { MALDI-TOF MS, } \\
\text { protein sequencing }\end{array}$ & $\begin{array}{l}\text { Energy (glycolysis, fermentation), glycoprotein } \\
\text { biosynthesis }\end{array}$ & 259 \\
\hline Flooding & $\begin{array}{l}\text { 2-DE (IPG), } \\
\text { MALDI-TOF MS, } \\
\text { ESI-MS/MS }\end{array}$ & $\begin{array}{l}\text { Energy (glycolysis, fermentation), amino acid } \\
\text { synthesis }\end{array}$ & 169 \\
\hline Flooding & $\begin{array}{l}\text { 2-DE (IEF/IPG tube } \\
\text { gel), MALDI-TOF } \\
\text { MS, LC-MS/MS, } \\
\text { protein sequencing }\end{array}$ & $\begin{array}{l}\text { Energy (glycolysis, pyruvate decarboxylation, } \\
\text { fermentation) antioxidant defence }\end{array}$ & 175 \\
\hline $\begin{array}{l}\text { Flooding } \\
\text { Low oxygen }\end{array}$ & $\begin{array}{l}\text { 2-DE (IEF), } \\
\text { MALDI-TOF MS, } \\
\text { LC-MS/MS }\end{array}$ & $\begin{array}{l}\text { Energy (glycolysis, pyruvate decarboxylation, } \\
\text { fermentation) }\end{array}$ & 260 \\
\hline Flooding, Salinity & $\begin{array}{l}\text { 2-DE (IPG), } \\
\text { MALDI-TOF MS }\end{array}$ & Energy, photosynthesis, glycoprotein biosynthesis & 261 \\
\hline Drought & $\begin{array}{l}\text { 2-DE (IPG), } \\
\text { LC-MS/MS }\end{array}$ & $\begin{array}{l}\text { Energy, photosynthesis, antioxidant defence, } \\
\text { glycoprotein biosynthesis, amino acid synthesis }\end{array}$ & 168 \\
\hline Drought & $\begin{array}{l}\text { 2-DE (IPG), } \\
\text { MALDI-TOF MS }\end{array}$ & $\begin{array}{l}\text { Antioxidant defence, amino acid synthesis, flavonoid } \\
\text { biosynthesis }\end{array}$ & 170 \\
\hline Osmotic stress & $\begin{array}{l}\text { 2-DE (IEF tube gel), } \\
\text { LC MS/MS }\end{array}$ & Antioxidant defence, glycoprotein biosynthesis & 262 \\
\hline Osmotic stress & $\begin{array}{l}\text { 2-DE (IEF tube gel), } \\
\text { MALDI-TOF MS, } \\
\text { protein sequencing }\end{array}$ & $\begin{array}{l}\text { Energy, antioxidant defence, glycoprotein } \\
\text { biosynthesis, amino acid synthesis }\end{array}$ & 263 \\
\hline
\end{tabular}




\begin{tabular}{|c|c|c|c|c|c|}
\hline Aldana & Root & $\begin{array}{l}\text { Osmotic, } \\
\text { Cold, }\end{array}$ & $\begin{array}{l}\text { 2-DE (IPG), } \\
\text { LC/ESI-MS }\end{array}$ & $\begin{array}{l}\text { Energy, antioxidant defence, fatty acid metabolism; } \\
\text { antioxidant defence; amino acid/nucleotide } \\
\text { metabolism }\end{array}$ & 165 \\
\hline $\begin{array}{l}\text { Harosoy } \\
\text { Fukuyutaka }\end{array}$ & $\begin{array}{l}\text { Leaf } \\
\text { Root }\end{array}$ & Cadmium & $\begin{array}{l}\text { 2-DE (IPG), } \\
\text { LC-MS/MS, } \\
\text { MALDI-TOF MS }\end{array}$ & $\begin{array}{l}\text { Energy, photosynthesis; antioxidant defence, } \\
\text { glycoprotein biosynthesis, amino acid synthesis }\end{array}$ & 167 \\
\hline Enrei Harosoy & Root micro-some & & $\begin{array}{l}\text { 2-DE (IPG), } \\
\text { LC-MS/MS }\end{array}$ & $\begin{array}{l}\text { Energy (fermentation), antioxidant defence, amino } \\
\text { acid synthesis }\end{array}$ & 179 \\
\hline Pioneer 93B15 & $\begin{array}{l}\text { Leaf } \\
\text { Root }\end{array}$ & Ozone & $\begin{array}{l}\text { 2-DE (IEF gel strip), } \\
\text { LC-MSMS }\end{array}$ & $\begin{array}{l}\text { Energy, photosynthesis, antioxidant defence, } \\
\text { flavonoid biosynthesis, amino acid/nucleotide } \\
\text { metabolism }\end{array}$ & 264 \\
\hline $\begin{array}{l}\text { Clark: } \\
\text { Standard, magenta }\end{array}$ & Leaf & UV-B & $\begin{array}{l}\text { 2-DE (IPG), } \\
\text { MALDI-TOF MS }\end{array}$ & $\begin{array}{l}\text { Photosynthesis, Energy, flavonoid biosynthesis, } \\
\text { antioxidant defence }\end{array}$ & 265 \\
\hline Lee68 N2899 & Germina-ting seed & Salinity & $\begin{array}{l}\text { 2-DE (IPG), } \\
\text { MALDI-TOF MS }\end{array}$ & Energy, antioxidant defence & 266 \\
\hline Enrei & $\begin{array}{l}\text { Leaf } \\
\text { Hypocotyl } \\
\text { Root }\end{array}$ & & $\begin{array}{l}\text { 2-DE (IEF tube gel), } \\
\text { MALDI-TOF MS, } \\
\text { protein sequencing }\end{array}$ & $\begin{array}{l}\text { Energy, photosynthesis, antioxidant defence; } \\
\text { glycoprotein biosynthesis, amino acid synthesis }\end{array}$ & 178 \\
\hline Enrei & $\begin{array}{l}\text { Hypocotyl } \\
\text { Root }\end{array}$ & & $\begin{array}{l}\text { 2-DE (IEF tube gel), } \\
\text { ESI-Q/TOF-MS/MS, } \\
\text { protein sequencing }\end{array}$ & Glycoprotein biosynthesis; antioxidant defence & 177 \\
\hline JG-62 & $\begin{array}{l}\text { Nucleus/3 week old } \\
\text { seedling }\end{array}$ & - & Gel-based/Gel-free & $\begin{array}{l}\text { Nuclear phosphoproteome of developing chickpea } \\
\text { seedlings and protein-kinase interaction network }\end{array}$ & 198 \\
\hline JG-62 and ICCV2 & $\begin{array}{l}\text { Nucleus/ } 3 \text { week old } \\
\text { seedling }\end{array}$ & Dehydration & Gel-based & $\begin{array}{l}\text { Nuclear proteome of a dehydration-sensitive } \\
\text { cultivar/tolerant cultivar. }\end{array}$ & 205 \\
\hline JG-62 & $\begin{array}{l}\text { Nucleus/ } 3 \text { week old } \\
\text { seedling }\end{array}$ & Dehydration & Gel-based & $\begin{array}{l}\text { Proteomics approach to identify dehydration } \\
\text { responsive nuclear proteins }\end{array}$ & 192 \\
\hline ICCV2 & $\begin{array}{l}\text { Extracellular matrix/ } \\
3 \text { week old seedling }\end{array}$ & Dehydration & Gel-based & $\begin{array}{l}\text { Dehydration-responsive reversible/ irreversible } \\
\text { changes in the extracellular matrix }\end{array}$ & 194 \\
\hline JG-62 & $\begin{array}{l}\text { Total//3 week old } \\
\text { seedling }\end{array}$ & Dehydration & Gel-based, Gel-free & $\begin{array}{l}\text { Phosphoproteomics of chickpea reveals shared and } \\
\text { distinct components of dehydration response. }\end{array}$ & 197 \\
\hline JG-62 & $\begin{array}{l}\text { Membrane/ } 3 \text { week } \\
\text { old seedling }\end{array}$ & - & Gel-based & $\begin{array}{l}\text { Proteomic analysis reveals the diversity and } \\
\text { complexity of membrane proteins in chickpea }\end{array}$ & 203 \\
\hline JG-62 & $\begin{array}{l}\text { Secretory/ } \\
\text { suspension culture }\end{array}$ & - & Gel-based & $\begin{array}{l}\text { secretome of suspension culture reveals pathway } \\
\text { abundance and the expected and unexpected secreted } \\
\text { proteins }\end{array}$ & 196 \\
\hline $\begin{array}{l}\text { Rupali, KH850, and } \\
\text { KJ850 }\end{array}$ & Seed & Germinated seeds & Gel-based & $\begin{array}{l}\text { genotypic variation in germination and early seedling } \\
\text { growth of chickpea under suboptimal soil-water } \\
\text { conditions }\end{array}$ & 267 \\
\hline Sel 96Th11439 & & Cold stress & Gel-based & $\begin{array}{l}\text { Physio-biochemical and proteome analysis of } \\
\text { chickpea in early phases of cold stress }\end{array}$ & 199 \\
\hline
\end{tabular}




\section{Page 75 of 77}

Journal of Proteome Research 


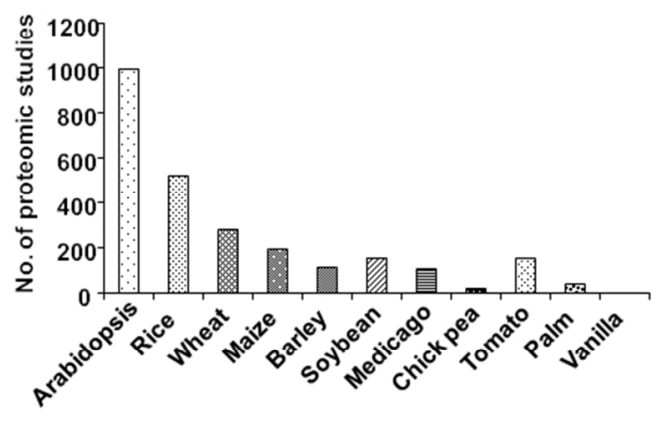

Figure 1.

\section{Comparison of number of proteomic studies amongst different crop plants based on PubMed search (www.pubmed.gov) (as of September 23, 2014). $190 \times 275 \mathrm{~mm}(96 \times 96 \mathrm{DPI})$}




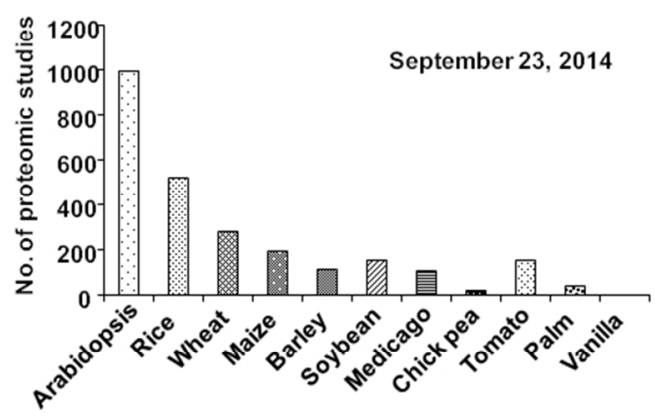

Graphical abstract

Graphical abstract $190 \times 275 \mathrm{~mm}(96 \times 96 \mathrm{DPI})$ 